\title{
Biodegradability of hydrothermally altered deep-sea dissolved organic matter
}

\author{
Christian T. Hansen ${ }^{\mathrm{a}, \mathrm{b}, *}$, Jutta Niggemann ${ }^{\mathrm{a}}$, Helge-Ansgar Giebel ${ }^{\mathrm{a}}$, Meinhard Simon ${ }^{\mathrm{a}, \mathrm{c}}$, \\ Wolfgang Bach ${ }^{\mathrm{b}}$, Thorsten Dittmar ${ }^{\mathrm{a}, \mathrm{c}}$ \\ ${ }^{a}$ Institute for Chemistry and Biology of the Marine Environment (ICBM), Carl von Ossietzky University of Oldenburg, Oldenburg 26129, Germany \\ ${ }^{\mathrm{b}}$ MARUM - Center for Marine Environmental Sciences, Bremen 28359, Germany \\ ${ }^{\mathrm{c}}$ Helmholtz Institute for Functional Marine Biodiversity at the University of Oldenburg (HIFMB), Germany
}

\section{A R T I C L E I N F O}

\section{Keywords:}

Dissolved organic matter

Hydrothermal degradation

Microbial degradation

Prokaryotes

Bioavailability

Experimental geochemistry

Fourier-transform ion cyclotron resonance

mass spectrometry

\begin{abstract}
A B S T R A C T
Deep-sea dissolved organic matter (DOM) constitutes a huge carbon reservoir in the worlds' oceans that - despite its abundance - is virtually unused as a substrate by marine heterotrophs. Heating within hydrothermal systems induces major molecular modifications of deep-sea DOM. Here, we tested the hypothesis that hydrothermal heating of deep-sea DOM enhances bioavailability. Aliquots of DOM extracted from the deep North Pacific (North Equatorial Pacific Intermediate Water; NEqPIW) were re-dissolved in artificial seawater and subjected to temperatures of 100 and $200^{\circ} \mathrm{C}(40 \mathrm{MPa})$ using Dickson-type reactors. In agreement with earlier findings we observed a temperature-related drop in dissolved organic carbon (DOC) concentration $\left(-6.1 \%\right.$ at $100{ }^{\circ} \mathrm{C}$, $-21.0 \%$ at $200^{\circ} \mathrm{C}$ ) that predominantly affected the solid-phase extractable (SPE-DOC) fraction $(-18.2 \%$ at $100{ }^{\circ} \mathrm{C},-51.4 \%$ at $200{ }^{\circ} \mathrm{C}$ ). Fourier-transform ion cyclotron resonance mass spectrometric (FT-ICR-MS) analysis confirmed a temperature-related reduction of average molecular mass, $\mathrm{O} / \mathrm{C}$ ratios, double bond equivalents (DBE) and a relative increase in aromaticity $\left(\mathrm{AI}_{\mathrm{mod}}\right)$. This thermally altered DOM was added $\left(25 \mu \mathrm{mol} \mathrm{L} \mathrm{L}^{-1} \mathrm{DOC}\right)$ to deep-water samples from the South West Pacific (Kermadec Arc, RV Sonne / SO253, 32 $37.706^{\prime} \mathrm{S} \mid 179^{\circ}$ $38.728^{\prime} \mathrm{W}$ ) and incubated with the prevailing natural microbial community. After 16 days at $4^{\circ} \mathrm{C}$ in the dark, prokaryotic cell counts in incubations containing the full spectrum of thermally-degraded DOM (extractable and non-extractable compounds) had increased considerably (on average $21 \times$ for $\mathrm{DOM}_{100^{\circ} \mathrm{C}}$ and $27 \times \mathrm{for}^{\mathrm{DOM}} \mathrm{M}_{200^{\circ} \mathrm{C}}$ ). In contrast, prokaryotic growth in incubations to which only solid-phase extractable thermally-altered DOM was added was not enhanced compared to control incubations. The experiments demonstrate that temperaturedriven degradation of deep-sea recalcitrant DOM within hydrothermal systems turns fractions of it accessible to microbes. The thermally-produced DOM compounds that stimulate microbial growth are not retained on reversed-phase resins (SPE-DOM) and are likely low-molecular mass organic acids. Despite the comprehensive compositional modifications of the solid-phase extractable (SPE-DOM) fraction through heating, it remains inaccessible to microbes at the investigated concentration levels. The microbial incubation resulted in only minor and mostly insignificant overall changes in SPE-DOM molecular composition and concentration.
\end{abstract}

\section{Introduction}

Marine dissolved organic matter (DOM) represents a large reservoir of reduced carbon $(662 \mathrm{Pg} \mathrm{C})$ in the ocean and it is equally important to marine heterotrophic life and the global carbon cycle (Dittmar and Stubbins, 2014; Hansell et al., 2009). DOM constitutes an extremely diverse mixture of hundreds of thousands of different organic molecules (Koch et al., 2005; Zark et al., 2017). This intriguing chemodiversity results from a complex system of interactions in the marine environment starting with phototrophic carbon fixation by phytoplankton and chemoautotrophic prokaryotes (Carlson and Hansell, 2015). DOM released by primary production is continuously turned over and reworked by a plethora of heterotrophic microorganisms, each releasing a unique set of exometabolites throughout their lifetime and during cell lysis (Carlson et al., 2007; Hansell, 2013; Kaiser and Benner, 2012; Wienhausen et al., 2017).

Most of the DOM production (15-25 $\mathrm{Pg} \mathrm{C}_{\text {year }}{ }^{-1}$ ) is considered labile and is quickly metabolized by microbes within minutes to weeks,

\footnotetext{
* Corresponding author at: Institute for Chemistry and Biology of the Marine Environment (ICBM), Carl von Ossietzky University of Oldenburg, Oldenburg 26129, Germany.

E-mail address: christian.hansen@uol.de (C.T. Hansen).
} 
while a much smaller fraction (combined $<3.8 \mathrm{Pg} \mathrm{C}_{\text {year }}{ }^{-1}$ ) resists microbial degradation for longer periods of time (Carlson and Hansell, 2015; Hansell et al., 2012; Jiao et al., 2010). As a consequence, part of DOM accumulates and is eventually exported from surface environments (epipelagic) to deeper waters (meso- and bathypelagic) by seasonal deepening of the pycnocline and through thermohaline circulation (Ducklow et al., 2001; Kragh and Søndergaard, 2009). Thus, even though the most recalcitrant forms of DOM are produced at low rate (0.043 Pg C year ${ }^{-1}$ ), they account for the majority of the global DOM budget (630 Pg C) (Hansell et al., 2012; Hansman et al., 2015). Consequently, DOM in the deep sea is not freshly produced and has an apparent radiocarbon age of 4000-6000 years (Flerus et al., 2012; Loh et al., 2004; Williams and Druffel, 1987). A major goal of recent research has been to identify processes that control the long-term stability and turnover of DOM. Besides a certain removal potential through interactions with sinking POM (Druffel et al., 1998; Druffel and Williams, 1990) and photodegradation (Stubbins et al., 2012), thermal degradation within hydrothermal systems holds a great potential as a sink for refractory DOM (Hawkes et al., 2015).

For unraveling DOM transformations on a molecular level, the development of advanced dedicated extraction methods and the sophisticated application of high-resolution analytical methods has been of key importance. A significant fraction of about $60 \%$ of the total dissolved organic carbon (DOC) can be retrieved by solid phase extraction of a filtered $(0.7-0.2 \mu \mathrm{m})$ and acidified water samples $(\mathrm{pH} 2)$ onto styrene divinyl benzene resins (PPL, Varian, Dittmar et al., 2008; Green et al., 2014). The desalination enables a subsequent detailed molecular characterization via techniques like nuclear magnetic resonance (NMR) spectroscopy or Fourier-transform ion cyclotron resonance mass spectrometry (FT-ICR-MS) (Hertkorn et al., 2013; Koch et al., 2005).

Detailed FT-ICR-MS based molecular characterization of DOM in hydrothermal fluid samples and from comparative thermal degradation experiments demonstrated that complete degradation of DOM is preceded by broad, rather indiscriminative compositional modifications (Hawkes et al., 2016; Rossel et al., 2017). The nature of hydrothermal DOM transformation observed in experiments indicates that at least a fraction is likely decomposed to small polar molecules, including acetate and formate, which are easily bioavailable (Hawkes et al., 2016; Winkel et al., 2014). Abiotic transformation processes in the extreme inorganic environment of hot springs on land may also result in the formation of specific DOM compounds (Gonsior et al., 2018). Hydrothermal systems could therefore act as a natural recycling reactor that returns a significant fraction of an otherwise inaccessible organic carbon reservoir back to active cycles.

Rossel et al. (2015) incubated a hydrothermal fluid sample from Woody vent $\left(55^{\circ} \mathrm{C}\right.$ diffuse discharge at the Menez Gwen hydrothermal system, Mid-Atlantic Ridge) with the resident microbial community. Within a relatively short time frame (7.5 days) they observed a pronounced depletion of unextractable DOC (-93\%) and total dissolved nitrogen (TDN, $-44 \%$ ) as well as a shift in CDOM (chromophoric DOM) patterns indicating that this change was related to microbial activity. At the same time, the solid-phase extractable DOC fraction (SPE-DOC) remained virtually unaffected. But while these results indicate that biodegradable DOC might be available in excess in hydrothermal systems, it has to be further investigated which of the many vent-associated processes this DOC fraction originates from, e.g. (1) insitu thermal degradation of DOM within the infiltrating seawater (2) insitu thermal degradation of organic material from autochthonous microbial communities, (3) remobilized sediment-hosted organic material, (4) abiotic synthesis involving Fisher-Tropsch-Type (FTT) reactions or (5) pristine synthetization from inorganic carbon (DIC) by chemosynthetic crustal microbial communities (Hawkes et al., 2016; McCarthy et al., 2011; Konn et al., 2009; McCollom and Seewald, 2003a).

Considering previous results from Rossel et al. (2015) and Hawkes et al. (2016) we designed a set of microbial degradation experiments incubating a local deep-sea microbial community from the Kermadec
Arc with deep-sea DOM that was previously altered under precisely controlled laboratory conditions (100 and $\left.200{ }^{\circ} \mathrm{C}, 40 \mathrm{MPa}\right)$. Through careful monitoring of prokaryotic growth (cell count), DOC and TDN as well as a detailed characterization of SPE-DOM molecular composition we investigated the following hypotheses.

(1) The purely abiotic temperature-driven compositional transformation of deep-sea DOM within hydrothermal systems results in an increased bioavailability of this DOM.

(2) Different fractions of the hydrothermally altered DOM (unextractable versus solid-phase extractable) are variably prone to subsequent biodegradation.

\section{Materials and methods}

\subsection{Preparation of hydrothermally altered DOM stock solutions}

In preparation of the incubations, stock solutions of deep water DOM were thermally degraded under laboratory conditions analogue to the procedure described in Hawkes et al. (2016). In brief, two extract aliquots of previously solid phase (PPL) extracted North Equatorial Pacific Intermediate Water (NEqPIW, 674 m, National Energy Laboratory of Hawaii Authority, Green et al., 2014) were dried $\left(50^{\circ} \mathrm{C}\right)$ and redissolved in an artificial seawater solution (Kester et al., 1967). As the volume available in the gold reactions cells was limited and considering the variable loss of DOC at the two reaction temperatures, we chose relatively high and variable initial concentration levels of DOC (8.5 and $10.0 \mathrm{mmol} \mathrm{L}^{-1}$ ) for the different autoclaved batches.

The two solution batches were subsequently thermally degraded using a customized Dickson-type autoclave that simulates conditions within hydrothermal systems (Dickson et al., 1963; Seyfried et al., 1987). Considering volume expansion at elevated temperatures, about $90 \mathrm{~mL}$ of the stock solutions were transferred into flexible gold reaction cells $\left(\mathrm{V}_{\text {total }} \approx 100 \mathrm{~mL}\right.$ ), which are firmly connected to a titanium access tube and valve with a customized gastight titanium bayonet closing mechanism. Each reaction cell was sealed inside a stainless-steel pressure vessel filled with distilled water, which itself was placed in an electric ceramic heater arrangement (Parr Instruments). The pressure medium surrounding the cell was connected to a pressure line for independent adjustment of pressure and temperature. Considering the findings of Hawkes et al. (2016) one batch was heated to $100{ }^{\circ} \mathrm{C}$ (23 days), the other to $200^{\circ} \mathrm{C}$ ( 15 days) while maintaining a constant pressure of $40 \mathrm{MPa}$. These temperature levels were chosen as the earlier experiments revealed significant compositional modifications while at the same time sufficiently high levels of DOC were maintained after reaching a steady state with regards to the thermal degradation. In-situ fluid samples from the running autoclavation were taken via the titanium access tube. This way, subsequent compositional changes during slow cooling were avoided. All components in contact with the fluid were either made of unreactive gold or passivated titanium. Aliquots were taken for quantification of DOC, TDN and molecular characterization of DOM following solid phase extraction (SPE-DOM). One half of the retrieved fluid volume $(\sim 20 \mathrm{~mL})$ from the two runs was immediately frozen, the other half was subjected to solid phase extraction (Varian PPL, Dittmar et al., 2008). The methanolic extract was dried under a stream of argon at room temperature and frozen for later redissolution. In summary, the procedure provided 5 derivates of the original NEqPIW SPE-DOM, an unaltered fraction [(1) SPE-DO$\left.M_{\text {unaltered }}\right]$ and two for each degradation temperature $\left(100\right.$ and $\left.200{ }^{\circ} \mathrm{C}\right)$ with one containing the entirety of the hydrothermally altered DOM [(2) $\mathrm{DOM}_{100^{\circ} \mathrm{C}}$ and (3) $\mathrm{DOM}_{200^{\circ} \mathrm{C}}$ ] and the other being limited to the solid phase extractable fraction of the hydrothermally altered DOM [(4)

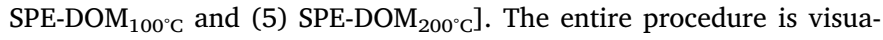
lized in Fig. 1. Note that the unaltered SPE-DOM fraction (1) was not temporarily stored inside a gold reaction cell and is hence not a perfect blank control in this regard. The risk of contamination (e.g. by 


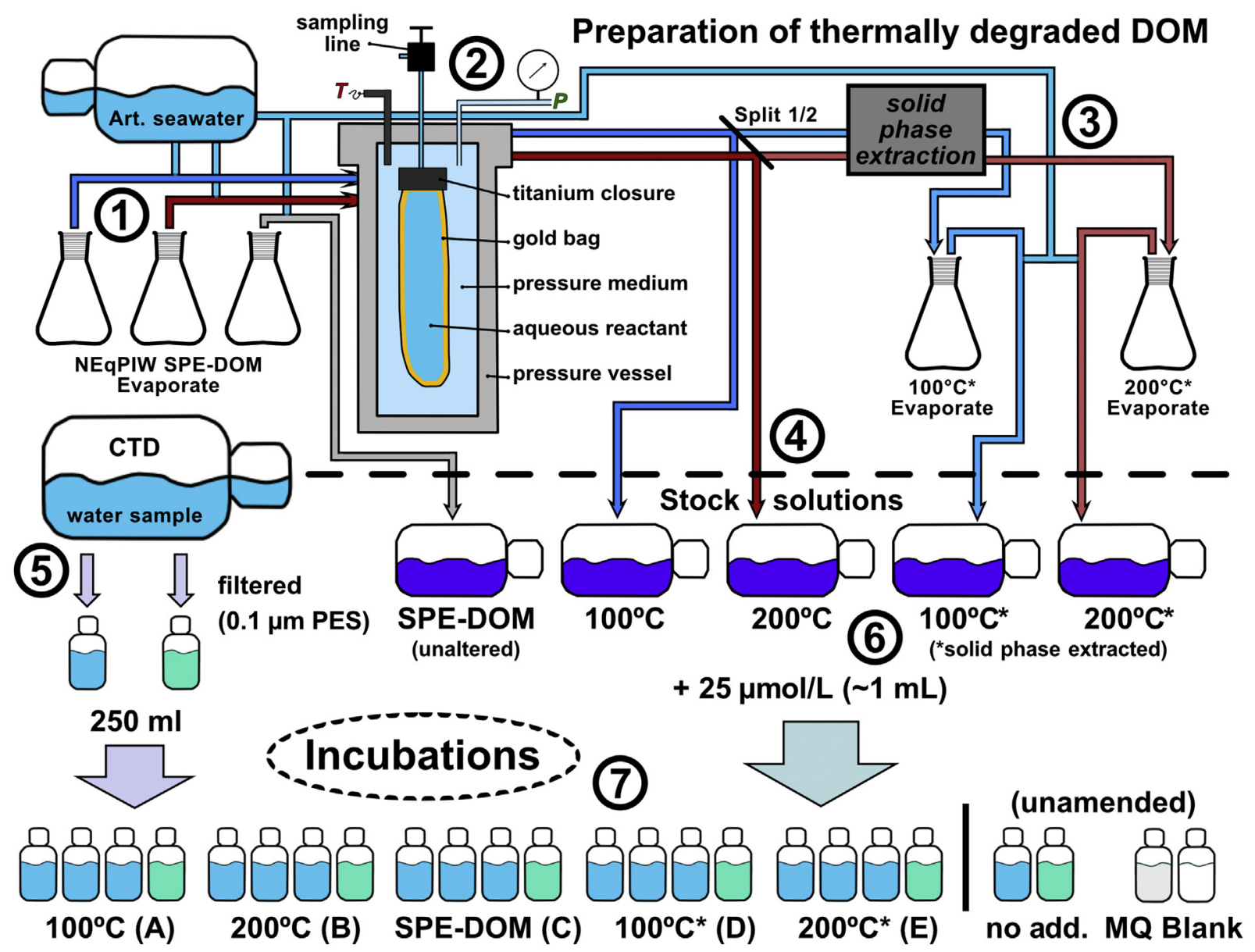

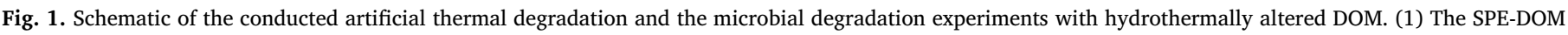

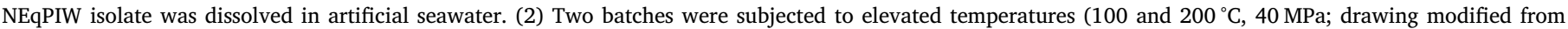

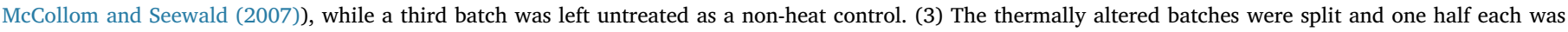

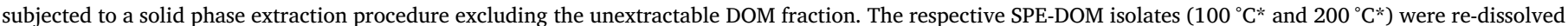

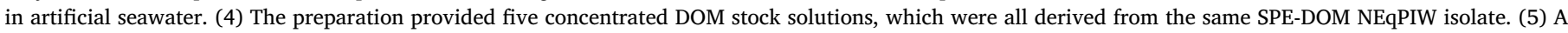

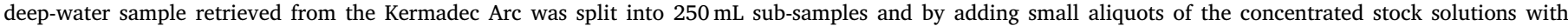

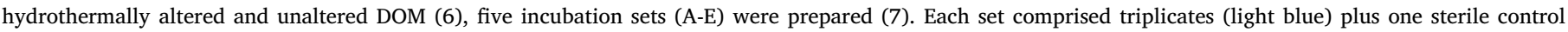

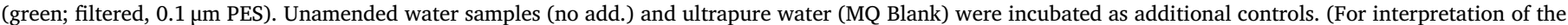
references to colour in this figure legend, the reader is referred to the web version of this article.)

nutrients, organics or trace metals) of the reacted batches, however, was minimal as the cells were thoroughly cleaned with concentrated acids $\left(\mathrm{HCl}\right.$ and $\mathrm{HNO}_{3}$ ) and ultrapure water, further combusted at $500{ }^{\circ} \mathrm{C}$ and rinsed with the reactant fluid prior to the experiments. Furthermore, the risk of compositional modification arising from potential microbial contamination during prolonged storage of a DOM enriched solution in the gold bag at room temperature is arguably much higher.

\subsection{Acquisition of deep-water sample from Kermadec Arc}

The aim of this study was to investigate to what degree originally recalcitrant deep-sea DOM that underwent thermal degradation within hydrothermal systems and reentered the deep open ocean is accessible to deep-sea microbes. For that purpose, we acquired a $10 \mathrm{~L}$ deep water sample in the South West Pacific during RV Sonne expedition SO253 to the Kermadec Arc, which is located north of New Zealand. The Kermadec Arc is part of the $2500 \mathrm{~m}$ long Tonga-Kermadec Arc that represents the trench-ridge system associated with the subduction of the Pacific plate under the Australian plate. Melting processes in the mantle wedge beneath and within the overriding Australian plate and injections of dehydration-derived water from the subducted plate give rise to pronounced volcanic and hydrothermal activity in the region (de
Ronde et al., 2007; de Ronde and Stucker, 2015). While our priority was not to investigate the biodegradability of hydrothermally modified DOM by microbial communities that directly colonize vent systems, we chose this overall hydrothermally active region of the ocean assuming that the local deep-sea microbes might be more adapted to thrive on thermally degraded DOM. Sampling was done using a SBE32 carousel water sampler with 22 Niskin bottles ( $10 \mathrm{~L}$ each) with a CTD unit (Koschinsky, 2017). Our deep water sample was retrieved from a water depth of $1548 \mathrm{~m}$ near the volcano Haungaroa $\left(32^{\circ} 37.706^{\prime} \mathrm{S} \mid 179^{\circ}\right.$ $38.728^{\prime} \mathrm{W}$ ), transferred to $2 \mathrm{~L}$ Nalgene bottles (pre-cleaned with ultrapure $0.01 \mathrm{M} \mathrm{HCl}$ and thoroughly rinsed with ultrapure water) and immediately stored in the dark at $4{ }^{\circ} \mathrm{C}$. Even though the sample was taken close to Haungaroa volcano it can be considered carrying a typical local DOM background as it was taken in a fair distance from the venting sites outside the caldera (Fig. 2). All sensors integrated in the CTD unit SBE911plus (temperature, conductivity) as well as additional sensors for oxygen $(2 \times$ SBE43), optical backscatter (Seapoint Turbidity Meters; $5 \times$ normal gain) and oxidation reduction potential (PMEL) produced inconspicuous values (consistent with local background) during the sampling procedure (Koschinsky, 2017). 


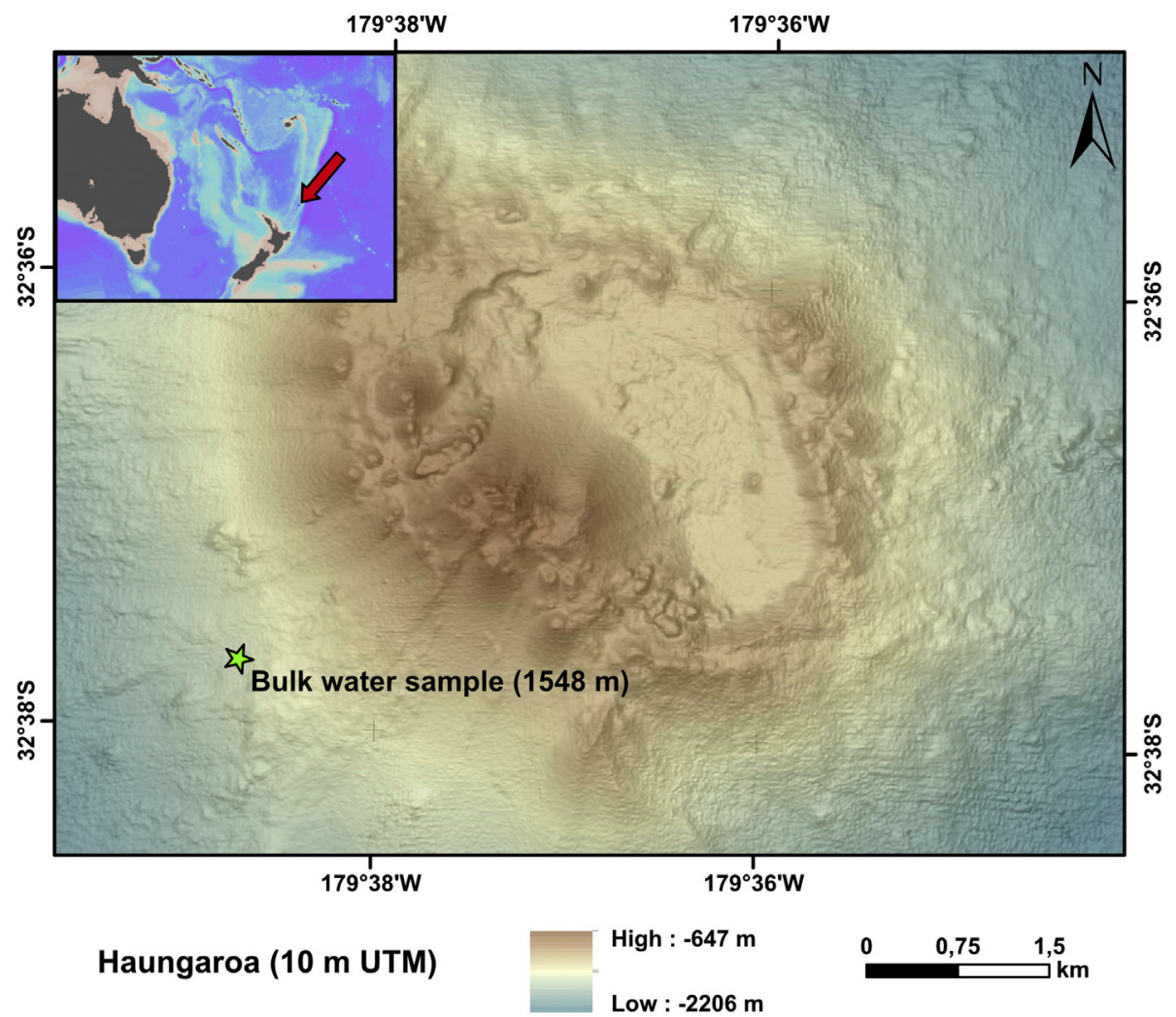

Fig. 2. Sampling location in the vicinity of Haungaroa volcano in the Kermadec Arc within the Pacific Ocean. Small inset produced with Ocean Data View (Schlitzer, 2018).

\subsection{Microbial degradation experiments}

After subsampling the bulk deep-water sample for determination of initial DOC and TDN concentrations and SPE, it was split into aliquots of $250 \mathrm{~mL}$ which were transferred into $250 \mathrm{~mL}$ polycarbonate Nalgene bottles (pre-cleaned as described in Section 2.2). Triplicates ( $3 \times$ unfiltered) plus one sterile control $(1 \times$ filtered through $0.1 \mu \mathrm{m}$ PES syringe filters, pre-cleaned like described above) were set up for each of the 5 prepared DOM fractions (20 incubations in total; Fig. 1). The DOC concentration in each bottle was increased by $25 \mu \mathrm{mol} \mathrm{L}^{-1}$ through addition of a small aliquot $(\sim 1 \mathrm{~mL})$ of the respective stock solutions. The stock solutions were prepared by re-dissolving the dried SPE-DOM fractions in $10 \mathrm{~mL}$ of filtered deep water sample $(0.1 \mu \mathrm{m}, \mathrm{PES})$. A pair of unamended sample (no add.) and ultrapure water (MQ Blank) $(1 \times$ unfiltered, $1 \times$ filtered sterile each) were incubated alongside the amended samples under oxic conditions at $4{ }^{\circ} \mathrm{C}$ in the dark (Fig. 1). Subsamples for quantification of DOC and TDN concentrations and prokaryotic cell counts were collected at the start $\left(T_{0}\right)$, after 4 days $\left(T_{1}\right)$, 9 days $\left(\mathrm{T}_{2}\right)$ and upon termination of the experiment after 16 days $\left(\mathrm{T}_{\text {final }}\right)$. For DOC and TDN determination, duplicates of $10 \mathrm{~mL}$ were filtered $(0.2 \mu \mathrm{m}$, GHP Acrodisc, pre-rinsed with ultrapure water) into pre-combusted glass vials and acidified to $\mathrm{pH} 2$ with ultrapure $\mathrm{HCl}$ (stored at $4{ }^{\circ} \mathrm{C}$ in the dark). For quantification of prokaryotic growth, $1 \mathrm{~mL}$ of sample was transferred into a brown glass vial using a prerinsed pipette and fixed with $30 \mu \mathrm{L}$ of formaldehyde solution (37 wt.-\%; stored at $\left.-80^{\circ} \mathrm{C}\right)$. An extra $50 \mathrm{~mL}$ volume sample for the molecular characterization of SPE-DOM was taken at the start $\left(\mathrm{T}_{0}\right)$ and at the end $\left(\mathrm{T}_{\text {final }}\right)$. The exact volume was noted and solid phase extracted via a styrene divinyl benzene cartridge (100 mg, PPL, Varian, Dittmar et al., $2008)$ following filtration $(0.2 \mu \mathrm{m}, \mathrm{GHP})$ and acidification (pH 2 with ultrapure $\mathrm{HCl}$ ). All cartridges were pre-cleaned with methanol and acidified ultrapure water and after the extraction they were rinsed with acidified ultrapure water, dried under a $\mathrm{N}_{2}(\mathrm{~g})$ flow and ultimately the
DOM extracts were retrieved through elution with $1 \mathrm{~mL}$ methanol (stored at $-20^{\circ} \mathrm{C}$ ).

\subsection{DOC and TDN}

DOC and TDN were determined by the high temperature catalytic combustion method utilizing a Shimadzu TOC- $\mathrm{V}_{\mathrm{CPH}}$ analyzer. Repeated measurements of a deep-sea reference material (Hansell, Florida Strait, $700 \mathrm{~m}$ water depth, batch No. 9, 2009, $44 \mu \mathrm{mol} \mathrm{DOC} \mathrm{L}^{-1}$ ) and ultrapure water were used to determine accuracy $(<3 \%$ deviation of expected value), precision (relative standard deviation, RSD $\%<3 \%$ ) and LOD (limit of detection, $4 \mu \mathrm{mol} \mathrm{L}^{-1}$ ). For SPE-DOC concentrations, $100 \mu \mathrm{L}$ of the methanolic DOM extract were transferred into a pre-combusted glass vial, dried overnight in an oven $\left(50{ }^{\circ} \mathrm{C}\right)$, re-dissolved in $10 \mathrm{~mL}$ of ultrapure $0.01 \mathrm{M} \mathrm{HCl}$ and then analyzed like the regular DOC samples.

\subsection{Prokaryote abundance}

Total cell numbers of prokaryotes were quantified using a BD Accuri C6 flow cytometer after staining $400 \mu \mathrm{L}$ of the fixed sample (see details in Section 2.3) with $20 \mu \mathrm{L}$ of SYBR Green I Nucleic Acid Gel Stain (1:51 diluted in DMSO, Invitrogen). Details are described in Giebel et al. (2019).

\subsection{SPE-DOM characterization via ESI FT-ICR-MS}

In preparation of SPE-DOM molecular characterization via ultrahigh resolution mass spectrometry, 1:1 mixtures of methanol and ultrapure water were prepared from the methanolic extracts aiming for a final concentration of $5 \mathrm{mg} \mathrm{C} \mathrm{L}^{-1}$ SPE-DOC. After an additional filtration $(0.2 \mu \mathrm{m}$, PTFE syringe filter) analyses were performed on a 15 Tesla SolariX XR FT-ICR-MS (Bruker Daltonics) following constant flow injection $(2 \mu \mathrm{L} / \mathrm{min})$ and electrospray ionization (ESI). The ionization 
source (Bruker Apollo II) was set to negative ionization mode ( $4 \mathrm{kV})$ and mass spectra $(\mathrm{m} / \mathrm{z} 50-1000 \mathrm{Da})$ were acquired after ion accumulation over $0.1 \mathrm{~s}$ and combination of 175 consecutive scans. The Bruker Daltonics Data Analysis software was used for individual calibration of each measurement with an internal calibration list derived from the inhouse NEqPIW reference standard.

A dedicated VBA script was used to export calibrated spectra related data of all measurements directly from the Data Analysis software and initially identify all peaks. The number of peaks was then reduced significantly by application of a method detection limit (MDL) introduced by Riedel and Dittmar (2014). An inhouse MatLab routine combined all measurements into one Excel file and assigned all possible combinations of $\mathrm{C}, \mathrm{H}, \mathrm{O}, \mathrm{N}, \mathrm{S}$ and $\mathrm{P}$ to each peak $(\mathrm{m} / \mathrm{z})$ with the following restrictions: $\mathrm{C} \geq \mathrm{O} ; \mathrm{O}>(2 \mathrm{P}+\mathrm{S}) ; \mathrm{H} \leq 2 \mathrm{C}+2 ; N \leq 4 ; \mathrm{S} \leq 2$ and $P \leq 1$. Detected masses with no molecular formula assigned were removed and in cases of double assignments, unlikely formulae were eliminated considering homologous series $\left(\mathrm{CH}_{2}\right)$ and prohibiting combination including NSP, $\mathrm{N}_{2} \mathrm{~S}, \mathrm{~N}_{3} \mathrm{~S}, \mathrm{~N}_{4} \mathrm{~S}, \mathrm{~N}_{2} \mathrm{P}, \mathrm{N}_{3} \mathrm{P}, \mathrm{N}_{4} \mathrm{P}, \mathrm{NS}_{2}, \mathrm{~N}_{2} \mathrm{~S}_{2}, \mathrm{~N}_{3} \mathrm{~S}_{2}$, $\mathrm{N}_{4} \mathrm{~S}_{2}, \mathrm{~S}_{2} \mathrm{P}$ as well as all compounds with 3 or more heteroatoms (N, S, P) except for $\mathrm{N}_{3}$ and $\mathrm{N}_{4}$. Elemental counts (C, H, O, N, S and P), ratios (H/ $\mathrm{C}, \mathrm{O} / \mathrm{C})$ and derived indices $(D B E=1+0.5 \cdot(2 C-H+N+P)$ and $A I_{\text {mod }}=(1+C-0.5 \cdot O-S-0.5 \cdot(N+P+H)) /$

$(C-0.5 \cdot O-S-N-P)$; Koch and Dittmar, 2016, Koch and Dittmar, 2006) were calculated. Molecular formulae were assigned to certain molecular groups as described by Rossel et al. (2015) (e.g. peptide- or polyphenol-like, highly unsaturated $\mathrm{O}_{\text {rich }} / \mathrm{O}_{\text {poor }}$, unsaturated aliphatics, saturated fatty acids and sugars). Peaks detected in the procedural blanks and original solvents (methanol and ultrapure water) were excluded from the samples if peak intensity was higher than in the much higher diluted samples. Also singlets, i.e. masses that occurred in only one mass spectrum, as well as common contaminants were removed from the dataset. The total number of formulae was further reduced by limitation to a $m / z$ ratio between 100 and $800 \mathrm{Da}$. For robust statistical analyses, the mass list of each sample was limited to 2500 most common formulae with respect to intensity. After normalization to total intensity, intensity weight averages were calculated for each sample including selected characteristics as elemental ratios (i.e. O/C, H/C), indices $\left(\mathrm{AI}_{\mathrm{mod}}, \mathrm{DBE}\right)$ and molecular categories. These were subsequently used in combination with external factors like temperature of the preceding thermal degradation and cell count to identify possible relations between the latter and variations of SPE-DOM molecular characteristics. Bray-Curtis dissimilarity matrices were calculated (R, vegan package, Oksanen et al., 2017), visualized in heatmaps and further analyzed through Principal Coordinate Analysis (PCoA) to further identify potential correlations or systematic changes. An early stage of the data evaluation revealed that three FT-ICR-MS mass spectra were potentially corrupted as they produced very different basic chemical characteristics (i.e. average $\mathrm{m} / \mathrm{z}$ or $\mathrm{O} / \mathrm{C}$ ) and deviated unreasonably from the other two methodological replicates from the same incubation set. As the samples were otherwise inconspicuous with respect to total cell count, DOC and SPE-DOC, and the corresponding sample from the start or end of the incubation was consistent with the other replicates, the suspicious mass spectra were excluded from further consideration. To maintain balance between the different incubation sets in the dataset, one random sample was consequently excluded from all sets of replicates.

\section{Results and discussion}

\subsection{Changes in DOC and SPE-DOC imposed by thermal degradation}

The thermal degradation at $100{ }^{\circ} \mathrm{C}$ resulted in a $6.1 \%$ reduction in DOC and an $18.2 \%$ reduction in SPE-DOC (Table 1 ). At $200^{\circ} \mathrm{C}$, autoclavation reduced total DOC by $21 \%$, whereas $51.4 \%$ of SPE-DOC was decomposed or removed from the extractable window. These results match the observations in earlier thermal degradation experiments conducted by Hawkes et al. (2016), who reported a $22.5 \%\left(100{ }^{\circ} \mathrm{C}\right)$ and $55.9 \%\left(200{ }^{\circ} \mathrm{C}\right)$ reduction of SPE-DOC, respectively. While the DOM used to prepare the initial solution should consist entirely of extractable compounds (as it was originally retrieved by solid phase extraction of NEqPIW), repeated solid phase extraction always results in a partial loss. Thus, the SPE-DOC concentration of an extracted aliquot of the initial solution was used as reference value to calculate the respective reduction through thermal degradation (Table 1).

\subsection{Prokaryotic growth and DOC in the microbial degradation experiments}

The variations in prokaryotic cell abundance, and DOC and SPEDOC concentrations clearly revealed a response of the deep-sea microbial communities from Kermadec Arc to the addition of different thermally altered and unaltered DOM (Table 2). The bulk water sample which was used for the incubations had an original DOC concentration of $48 \mu \mathrm{mol} \mathrm{L}^{-1}$, typical for meso-bathypelagic water (Dittmar and Stubbins, 2014). The targeted uniform concentration increase of $25 \pm 2 \mu \mathrm{mol} \mathrm{L}^{-1}$ was accomplished by the addition of small aliquots of the prepared concentrated stock solutions (Fig. 3). All incubations also started with a nearly identical prokaryotic cell abundance around $0.3 \cdot 10^{5}$ cells $\mathrm{mL}^{-1}$, while the absence of cells was confirmed for all sterile controls as well as a control incubation of ultrapure water (MQ Blank) (Fig. 4 and Table 2). As expected, the incubations to which reextracted thermally-altered DOM was added had higher concentrations of SPE-DOC $\left(58 \pm 1.4 \mu \mathrm{mol} \mathrm{L}^{-1}\right)$ than those where the bulk of thermally altered DOM was added $\left(100^{\circ} \mathrm{C}: 53 \mu \mathrm{mol} \mathrm{L}^{-1}\right.$ and $200^{\circ} \mathrm{C}$ : $46 \mu \mathrm{mol} \mathrm{L}^{-1}$; Fig. 5). This difference in SPE-DOC concentrations is clear evidence for the formation of non-extractable DOC, likely small ionic compounds, during thermal degradation. Combined, all variables confirmed the desired initial conditions.

The early phase of the experiment was characterized by overall very limited changes. DOC gradually increased slightly in all incubations including sterile and blank controls (Fig. 3), possibly indicating some contamination from the incubation container material despite thorough prior cleaning. It is unlikely that this initial DOC increase was related to chemoautotrophic activity as cell numbers remained virtually unchanged at a very low level. First signs of significant prokaryotic growth were observed after 9 days within those incubations where the bulk of thermally-altered DOM was added $\left(100{ }^{\circ} \mathrm{C}\right.$ : 1.5 and $200{ }^{\circ} \mathrm{C}$ : 3.1 times increase in total cells; Fig. 4). Cell abundance remained unchanged in all other bottles. As the experiments advanced, prokaryotic growth eventually occurred in all incubations, with the exception of ultrapure water (Fig. 4). However, in those experiments where re-extracted DOM was added, the increase in cell numbers was undistinguishable from the non-heat control as well as the control with no addition of DOM. In these incubations, the cell numbers increased on average by factor $10 \pm 2$ in the course of the experiment (Table 2). In contrast, prokaryotic growth was far more stimulated in the incubations with addition of thermally-altered bulk DOM (extractable and non-extractable). Addition of bulk DOM that was thermally altered at $100^{\circ} \mathrm{C}$ resulted in an increase of cell abundance by factor 21 , addition of DOM that was thermally altered at $200^{\circ} \mathrm{C}$ enhanced cell abundance even more (factor 27; Table S1). This result suggests that a significant portion of the observed prokaryotic growth was exclusively stimulated by the non-extractable DOM fraction produced during thermal degradation. Furthermore, alteration at higher temperatures appears to convert a higher percentage of formerly inaccessible SPE-DOM into utilizable, yet no longer extractable, DOM compounds. Additional targeted analysis following earlier degradation experiments by Hawkes et al. (2016), in which DOC levels were in the $\mathrm{mmol} \mathrm{L}^{-1}$ range, demonstrated that the prolonged subjection to elevated temperatures resulted in a significant production of acetate and formate, which are well-known substrates for heterotrophic microorganisms (Hawkes et al., 2016; Lang et al., 2010; Windman et al., 2007; Winkel et al., 2014). But while these compounds are clearly detectable in a concentrated solution of several 
Table 1

DOC concentrations of artificial seawater solutions (bold) used to increase initial concentrations in the incubation experiments.

\begin{tabular}{|c|c|c|c|c|c|c|}
\hline Stock Solution & $\begin{array}{l}\text { DOC (SPE-DOC) original } \\
{\left[\mathrm{mmol} \mathrm{L}^{-1}\right]}\end{array}$ & $\begin{array}{l}\text { Thermal } \\
\text { Degradation }\end{array}$ & $\begin{array}{l}\text { DOC after heating } \\
{\left[\mathrm{mmol} \mathrm{L}^{-1}\right]}\end{array}$ & $\begin{array}{l}\text { Solid Phase } \\
\text { Extraction }\end{array}$ & $\begin{array}{l}\text { SPE-DOC after heating } \\
{\left[\mathrm{mmol} \mathrm{L}^{-1}\right]}\end{array}$ & $\begin{array}{l}\text { SPE-DOC (orig. - after } \\
\text { heating) }[\%]\end{array}$ \\
\hline $\mathrm{NEqPIW}_{\text {unaltered }}$ & 5.47 & - & - & - & - & - \\
\hline $\mathrm{NEqPIW}_{100^{\circ} \mathrm{C}}$ & $8.66(7.21)$ & $\rightarrow$ minus $6.1 \%$ & 8.14 & $\rightarrow$ minus $27.5 \%$ & 5.90 & 18.2 \\
\hline $\mathrm{NEqPIW}_{200^{\circ} \mathrm{C}}$ & $10.18(8.89)$ & $\rightarrow$ minus $21.0 \%$ & 8.05 & $\rightarrow$ minus $46.3 \%$ & 4.32 & 51.4 \\
\hline
\end{tabular}

Table 2

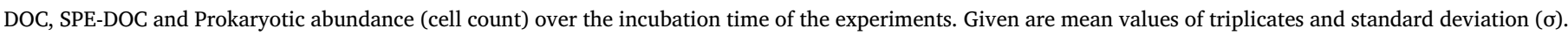
Sterile controls are indicated by subscripted $S$.

\begin{tabular}{|c|c|c|c|c|c|c|c|c|c|c|}
\hline \multirow[t]{2}{*}{ Incubation Set } & Time & DOC & $\sigma \mathrm{DOC}$ & $\mathrm{DOC}_{\mathrm{S}}$ & SPE-DOC & $\sigma$ SPE-DOC & SPE-DOC $S$ & Cell count & $\sigma$ Cell count & Cell counts \\
\hline & [days] & {$\left[\mu \mathrm{mol} \mathrm{L}^{-1}\right]$} & {$\left[\mu \mathrm{mol} \mathrm{L}^{-1}\right]$} & {$\left[\mu \mathrm{mol} \mathrm{L}^{-1}\right]$} & {$\left[\mu \mathrm{mol} \mathrm{L}^{-1}\right]$} & {$\left[\mu \mathrm{mol} \mathrm{L}^{-1}\right]$} & {$\left[\mu \mathrm{mol} \mathrm{L}^{-1}\right]$} & {$\left[\mathrm{mL}^{-1}\right]$} & {$\left[\mathrm{mL}^{-1}\right]$} & {$\left[\mathrm{mL}^{-1}\right]$} \\
\hline $\operatorname{DOM}\left(100^{\circ} \mathrm{C}\right)$ & 0 & 76 & 3 & 71 & 53 & 1.2 & 49 & 30,066 & 1425 & 357 \\
\hline \multirow[t]{3}{*}{ Set A } & 4 & 78 & 2 & 73 & & & & 27,912 & 1166 & 273 \\
\hline & 9 & 84 & 4 & 92 & & & & 46,166 & 1111 & 63 \\
\hline & 16 & 66 & 2 & 86 & 55 & 2.4 & 53 & 641,649 & 23,669 & 42 \\
\hline $\operatorname{DOM}\left(200^{\circ} \mathrm{C}\right)$ & 0 & 70 & 1 & 69 & 46 & 3.0 & 41 & 31,004 & 3319 & 105 \\
\hline \multirow[t]{3}{*}{ Set B } & 4 & 77 & 7 & 79 & & & & 28,612 & 1418 & 105 \\
\hline & 9 & 75 & 2 & 85 & & & & 95,319 & 8568 & 84 \\
\hline & 16 & 61 & 1 & 87 & 45 & 1.6 & 42 & 839,042 & 110,308 & 105 \\
\hline DOM = SPE-DOM & 0 & 73 & 1 & 72 & 56 & 1.4 & 59 & 32,021 & 1974 & 231 \\
\hline Non-heat control & 4 & 81 & 2 & 77 & & & & 28,940 & 1302 & 315 \\
\hline \multirow[t]{2}{*}{ Set C } & 9 & 85 & 3 & 87 & & & & 26,507 & 894 & 420 \\
\hline & 16 & 75 & 2 & 88 & 60 & 2.4 & 64 & 246,609 & 160,892 & 147 \\
\hline SPE-DOM $\left(100^{\circ} \mathrm{C}\right)$ & 0 & 74 & 2 & 74 & 60 & 0.2 & 58 & 29,794 & 881 & 105 \\
\hline \multirow[t]{3}{*}{ Set D } & 4 & 79 & 7 & 74 & & & & 27,199 & 483 & 252 \\
\hline & 9 & 83 & 5 & 81 & & & & 28,808 & 4909 & 273 \\
\hline & 16 & 75 & 7 & 82 & 63 & 2.8 & 66 & 234,783 & 143,217 & 147 \\
\hline SPE-DOM $\left(200^{\circ} \mathrm{C}\right)$ & 0 & 73 & 1 & 71 & 58 & 2.5 & 63 & 29,241 & 1030 & 147 \\
\hline \multirow[t]{3}{*}{ Set E } & 4 & 78 & 5 & 76 & & & & 26,961 & 1365 & 231 \\
\hline & 9 & 85 & 3 & 92 & & & & 26,598 & 1081 & 168 \\
\hline & 16 & 67 & 2 & 92 & 63 & 2.2 & 68 & 375,967 & 104,144 & 315 \\
\hline \multirow[t]{4}{*}{ No addition control } & 0 & 48 & 1 & 50 & 32 & & 22 & 32,647 & 1030 & 420 \\
\hline & 4 & 55 & 5 & 55 & & & & 27,654 & 1365 & 252 \\
\hline & 9 & 60 & 3 & 71 & & & & 24,653 & 1081 & 126 \\
\hline & 16 & 45 & 2 & 70 & 35 & & 31 & 335,809 & 104,144 & 147 \\
\hline \multirow[t]{4}{*}{ MQ Blank } & 0 & 12 & & 18 & 8 & & 6 & 84 & & 713 \\
\hline & 4 & 16 & & 16 & & & & 189 & & 0 \\
\hline & 9 & 24 & & 26 & & & & 105 & & 63 \\
\hline & 16 & 30 & & 28 & 5 & & 8 & 42 & & 147 \\
\hline
\end{tabular}

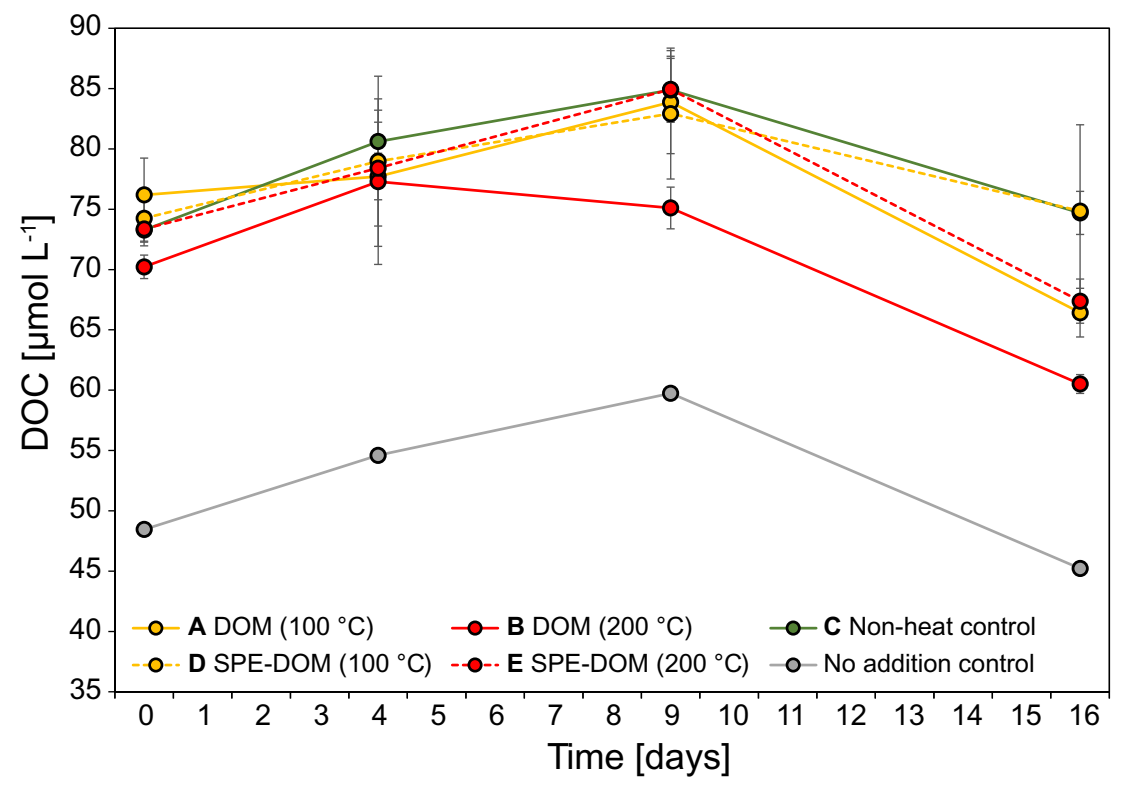

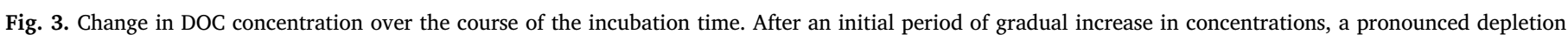
occurred in all incubations. 


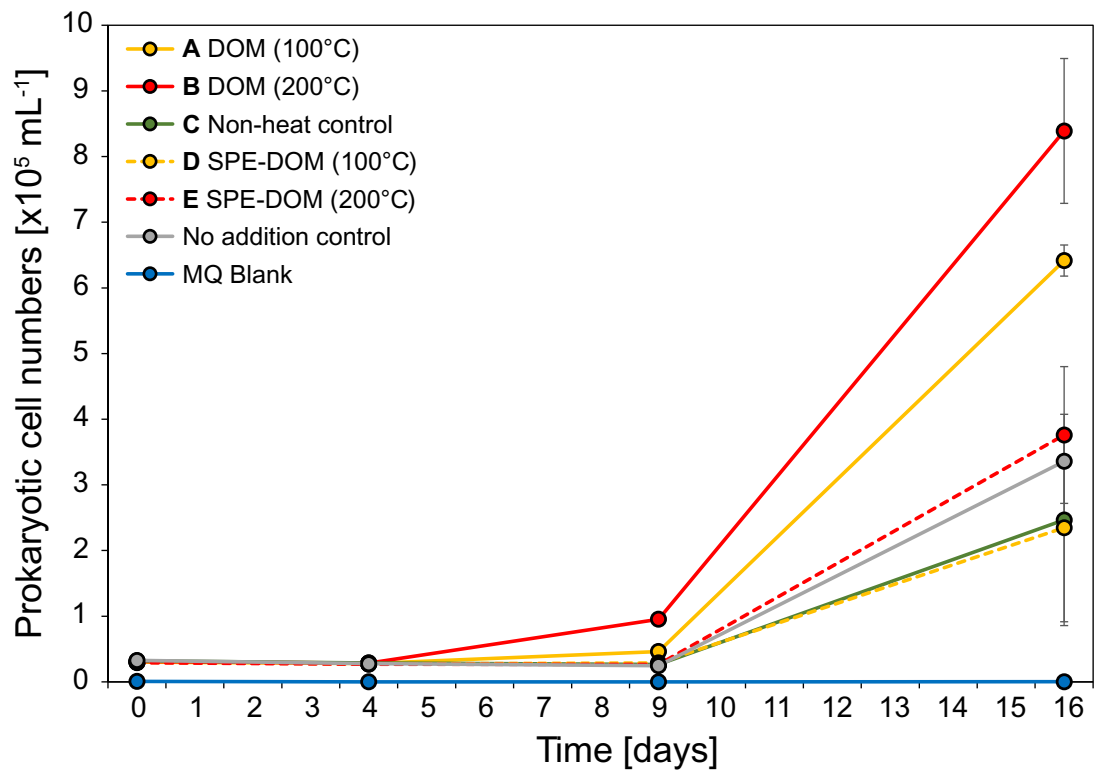

Fig. 4. Prokaryotic cell abundance throughout the incubations of deep-sea microbes from the Kermadec Arc with different batches of thermally altered DOM. The highest increase in cell abundance occurred in incubations with additions of extractable and non-extractable thermally altered DOM (set A and B). In contrast, an identical DOC concentration increase, exclusively due to the extractable fraction, resulted in no significant increase in cell numbers compared to an incubation without additional DOM (set C, D and $\mathrm{E}$ versus no addition control). Each datapoint represents the average of three experimental replicates with error bars indicating the standard deviation of the triplicate incubations. Comparative incubations of batches without additional DOM (no. add.) and ultrapure water (MQ Blank) were not conducted in triplicates.

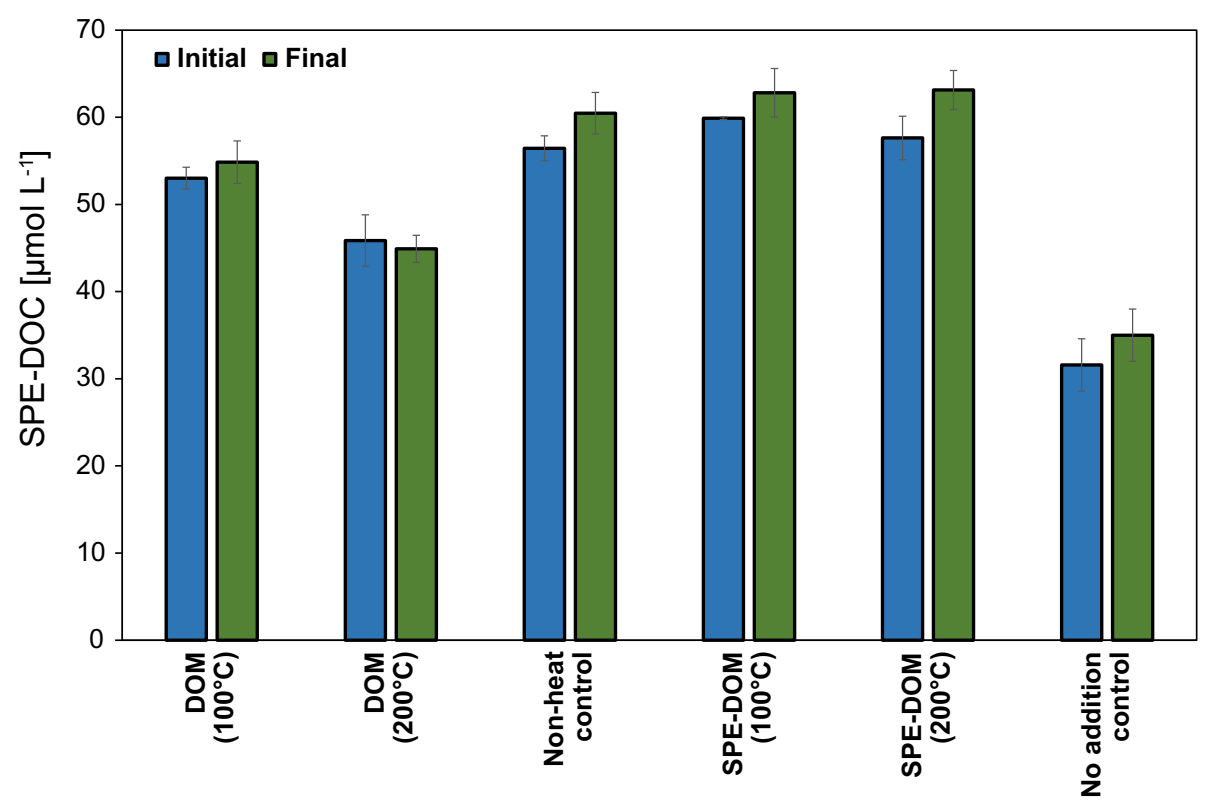

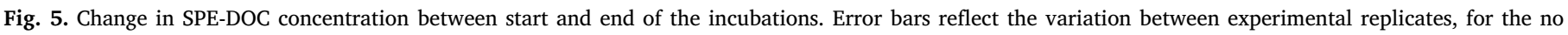
addition control (no add.) incubation, they indicate the error (RSD\%) of the measurement.

mmol L $\mathrm{L}^{-1}$ DOC, their individual concentration in the microbial degradation experiments would still be too low for any reliable quantification (Heuer et al., 2006, 2009).

The clear systematic pattern in evolving cell numbers was consistent with changes in DOC concentrations. To estimate the expected DOC decrease due to microbial degradation, we calculated the amount of carbon the observed microbial growth should translate to, based on cell numbers $(\mathrm{n})$, typical carbon content per cell $\left(\mathrm{C}_{\text {cell }}\right)$ and average cell diameter $\left(\mathrm{d}_{\text {cell }}\right)$, with the latter being determined during flow cytometric analysis. Average cell diameter in final fluid samples from the experiments was fairly uniform with $0.52 \pm 0.01 \mu \mathrm{m}\left(\mathrm{d}_{\text {cell }}\right)$, which translates to a cell volume of $0.074 \mu \mathrm{m}^{3}$ (assuming spherical cell geometry). The volume-dependent carbon equivalent of a corresponding prokaryotic cell $\left(\mathrm{C}_{\text {cell }}\right)$ was interpolated using data from Simon and Azam (1989).

The resulting $\mathrm{C}_{\text {cell }}$ of approximately $19.3 \cdot 10^{-15} \mathrm{~g} \mathrm{C}$ cell $^{-1}$ would translate to a carbon concentration of $0.33-1.35 \mu \mathrm{mol} \mathrm{L}^{-1}$ between the lowest and highest average cell count from the conducted experiments $\left(2.05 \cdot 10^{5}\right.$ and $8.08 \cdot 10^{5}$ cells for incubation sets D and B). To estimate the amount of DOC consumption required for cell growth, one has to consider prokaryotic growth efficiency (PGE), i.e. the ratio of new biomass produced per unit of organic $C$ substrate assimilated. If we assume a PGE of 10\% (del Giorgio et al., 1997; Eiler et al., 2003), the magnitude of the observed DOC depletion during the incubations was consistent with the observed prokaryotic growth. We observed a slightly higher DOC depletion for the sets with a higher increase in prokaryotic cells. However, the differences were small and, considering the analytical error of DOC determination, not significant. Nevertheless, and independent of actual PGE, the changes in DOC were consistent with the observed prokaryotic growth and no comparable DOC depletion was observed in any of the sterile controls (Table 2). The causal relation between observed changes in DOC and prokaryotic growth is further supported by the fact that no considerable decrease in DOC occurred before any notable increase in prokaryotic abundance. After 

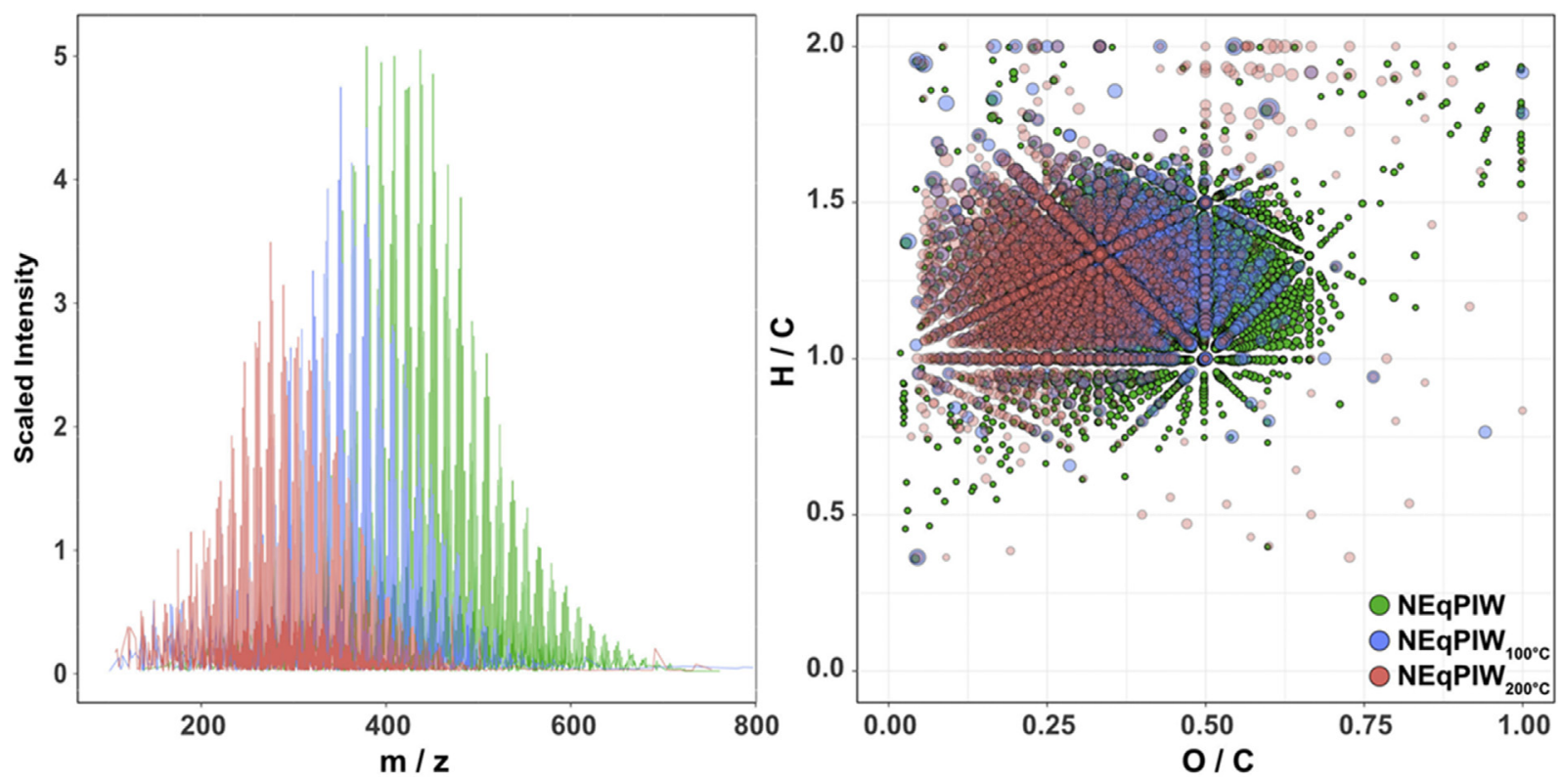

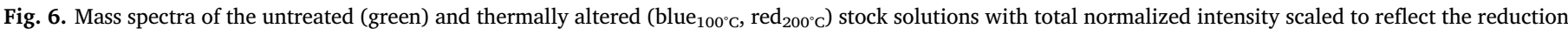

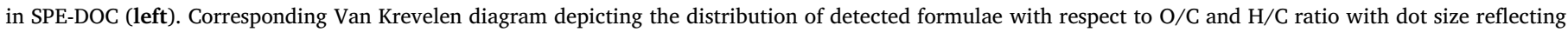

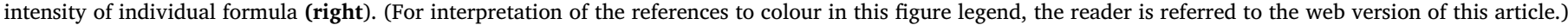

Table 3

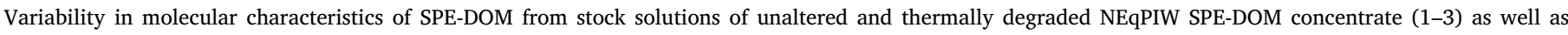

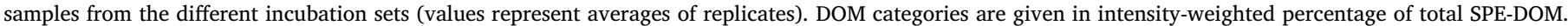

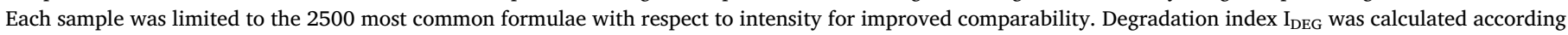

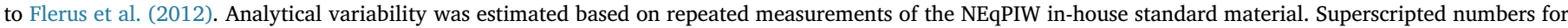

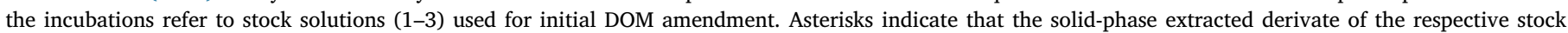

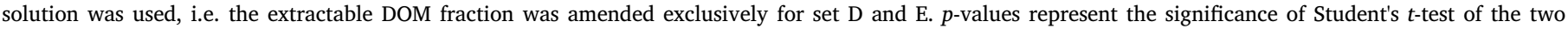

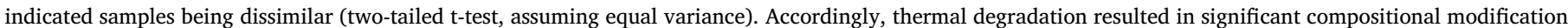

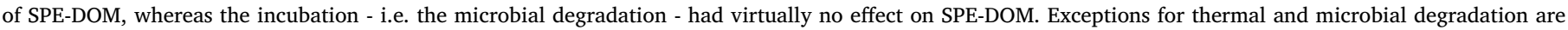
marked in bold lettering (threshold $p=.01$ ).

\begin{tabular}{|c|c|c|c|c|c|c|c|c|c|c|c|}
\hline Sample ID & $\mathrm{m} / \mathrm{z}$ & $\mathrm{O} / \mathrm{C}$ & $\mathrm{AI}_{\mathrm{mod}}$ & DBE & Polyphenol* $\mathrm{O}_{\text {poor }}$ & H.unsat. $\mathrm{O}_{\text {rich }}$ & H.unsat. $\mathrm{O}_{\text {poor }}$ & Unsat. Aliph. $\mathrm{O}_{\text {rich }}$ & Unsat. Aliph. $\mathrm{O}_{\text {poor }}$ & Peptides* & $\mathrm{I}_{\mathrm{deg}}$ \\
\hline (1) NEqPIW unaltered & 431 & 0.43 & 0.25 & 8.90 & $6.6 \%$ & $20.9 \%$ & $59.6 \%$ & $1.6 \%$ & $5.0 \%$ & $2.2 \%$ & 0.86 \\
\hline (2) NEqPIW $100^{\circ} \mathrm{C}$ & 355 & 0.36 & 0.28 & 7.66 & $6.2 \%$ & $6.6 \%$ & $71.7 \%$ & $1.0 \%$ & $9.9 \%$ & $1.4 \%$ & 0.58 \\
\hline$p$-value (1)-(2) & 0.000 & 0.000 & 0.000 & 0.000 & 0.138 & 0.000 & 0.000 & 0.045 & 0.000 & 0.005 & 0.000 \\
\hline (3) $\mathrm{NEqPIW}_{200^{\circ} \mathrm{C}}$ & 306 & 0.28 & 0.33 & 7.34 & $13.1 \%$ & $2.0 \%$ & $64.1 \%$ & $2.6 \%$ & $9.3 \%$ & $2.4 \%$ & 0.45 \\
\hline$p$-value (1)-(3) & 0.000 & 0.000 & 0.000 & 0.000 & 0.000 & 0.000 & 0.002 & 0.001 & 0.000 & 0.409 & 0.000 \\
\hline $\operatorname{DOM}\left(100^{\circ} \mathrm{C}\right)_{\text {start }}(\mathrm{A})^{2}$ & 361 & 0.38 & 0.28 & 7.81 & $9.9 \%$ & $12.2 \%$ & $62.3 \%$ & $1.6 \%$ & $8.3 \%$ & $1.8 \%$ & 0.65 \\
\hline $\operatorname{DOM}\left(100^{\circ} \mathrm{C}\right)_{\text {end }}(\mathrm{A})^{2}$ & 364 & 0.38 & 0.28 & 7.80 & $10.2 \%$ & $13.1 \%$ & $61.6 \%$ & $1.7 \%$ & $8.2 \%$ & $1.8 \%$ & 0.67 \\
\hline$p$-value start-end $\mathrm{A}$ & 0.252 & 0.043 & 0.110 & 0.897 & 0.691 & 0.018 & 0.574 & 0.735 & 0.505 & 0.198 & 0.031 \\
\hline DOM $\left(200^{\circ} \mathrm{C}\right)_{\text {start }}(\mathrm{B})^{3}$ & 330 & 0.33 & 0.30 & 7.50 & $11.5 \%$ & $10.0 \%$ & $62.2 \%$ & $1.6 \%$ & $9.4 \%$ & $2.2 \%$ & 0.59 \\
\hline DOM $\left(200{ }^{\circ} \mathrm{C}\right)_{\text {end }}(B)^{3}$ & 334 & 0.33 & 0.30 & 7.57 & $11.2 \%$ & $10.3 \%$ & $63.0 \%$ & $1.9 \%$ & $8.4 \%$ & $1.8 \%$ & 0.61 \\
\hline$p$-value start-end $\mathrm{B}$ & 0.299 & 0.531 & 0.653 & 0.297 & 0.020 & 0.512 & 0.469 & 0.423 & 0.121 & 0.543 & 0.510 \\
\hline Non-heat control ${ }_{\text {start }}(C)^{1}$ & 391 & 0.41 & 0.26 & 8.25 & $7.8 \%$ & $17.9 \%$ & $63.0 \%$ & $1.4 \%$ & $6.8 \%$ & $1.4 \%$ & 0.77 \\
\hline Non-heat control $_{\text {end }}(C)^{1}$ & 388 & 0.41 & 0.27 & 8.21 & $8.7 \%$ & $17.9 \%$ & $62.0 \%$ & $1.5 \%$ & $6.6 \%$ & $1.1 \%$ & 0.77 \\
\hline$p$-value start-end $_{\text {C }}$ & 0.178 & 0.735 & 0.006 & 0.364 & 0.022 & 0.698 & 0.126 & 0.238 & 0.186 & 0.402 & 0.908 \\
\hline SPE-DOM $\left(100^{\circ} \mathrm{C}\right)_{\text {start }}(\mathrm{D})^{2_{*}}$ & 353 & 0.37 & 0.28 & 7.71 & $10.6 \%$ & $10.3 \%$ & $61.7 \%$ & $1.8 \%$ & $8.7 \%$ & $2.4 \%$ & 0.62 \\
\hline SPE-DOM $\left(100^{\circ} \mathrm{C}\right)_{\text {end }}(D)^{2_{*}}$ & 357 & 0.38 & 0.29 & 7.82 & $10.6 \%$ & $11.9 \%$ & $62.0 \%$ & $1.6 \%$ & $7.6 \%$ & $2.1 \%$ & 0.66 \\
\hline$p$-value start-end $\mathrm{D}$ & 0.102 & 0.050 & 0.263 & 0.260 & 0.198 & 0.050 & 0.720 & 0.015 & 0.123 & 0.034 & 0.021 \\
\hline SPE-DOM $\left(200^{\circ} \mathrm{C}\right)_{\text {start }}(\mathrm{E})^{3_{*}}$ & 317 & 0.31 & 0.31 & 7.29 & $12.0 \%$ & $7.2 \%$ & $61.6 \%$ & $2.2 \%$ & $9.7 \%$ & $2.7 \%$ & 0.53 \\
\hline SPE-DOM $\left(200^{\circ} \mathrm{C}\right)_{\text {end }}(E)^{3_{*}}$ & 328 & 0.32 & 0.31 & 7.57 & $12.1 \%$ & $8.8 \%$ & $63.3 \%$ & $2.0 \%$ & $8.7 \%$ & $1.9 \%$ & 0.57 \\
\hline$p$-value start-end $\mathrm{E}$ & 0.230 & 0.286 & 0.731 & 0.123 & 0.937 & 0.304 & 0.012 & 0.008 & 0.051 & 0.063 & 0.195 \\
\hline No addition control ${ }_{\text {start }}$ & 360 & 0.39 & 0.28 & 7.76 & $10.1 \%$ & $14.6 \%$ & $60.2 \%$ & $1.7 \%$ & $8.1 \%$ & $1.9 \%$ & 0.64 \\
\hline No addition control ${ }_{\text {end }}$ & 367 & 0.40 & 0.27 & 7.79 & $9.4 \%$ & $15.6 \%$ & $59.5 \%$ & $1.9 \%$ & $8.9 \%$ & $1.7 \%$ & 0.66 \\
\hline Average NEqPIW (6) & 419 & 0.45 & 0.24 & 8.53 & $6.1 \%$ & $22.5 \%$ & $60.9 \%$ & $1.8 \%$ & $6.6 \%$ & $0.7 \%$ & 0.84 \\
\hline$\sigma$ NEqPIW (6) & 6 & 0.01 & 0.00 & 0.11 & $0.4 \%$ & $1.7 \%$ & $0.9 \%$ & $0.1 \%$ & $0.8 \%$ & $0.1 \%$ & 0.01 \\
\hline
\end{tabular}

9 days, DOC had decreased only in the incubation where bulk DOM altered at $200{ }^{\circ} \mathrm{C}$ was added. In this set, the by far highest increase in prokaryotic abundance was observed at the same time point. In all other incubation, DOC consumption during the initial 9 days was still insufficient to counteract the mentioned input from an unknown contamination source. But as pronounced prokaryotic growth occurred in all DOM-containing incubations between day 9 and 16, DOC levels dropped accordingly throughout.

In contrast to total DOC, the extractable SPE-DOC fraction remained virtually unchanged in the five incubation sets and the control incubation (Fig. 5). The growing deep-sea microbial communities apparently did not use the extractable fraction of DOM as a carbon source, 


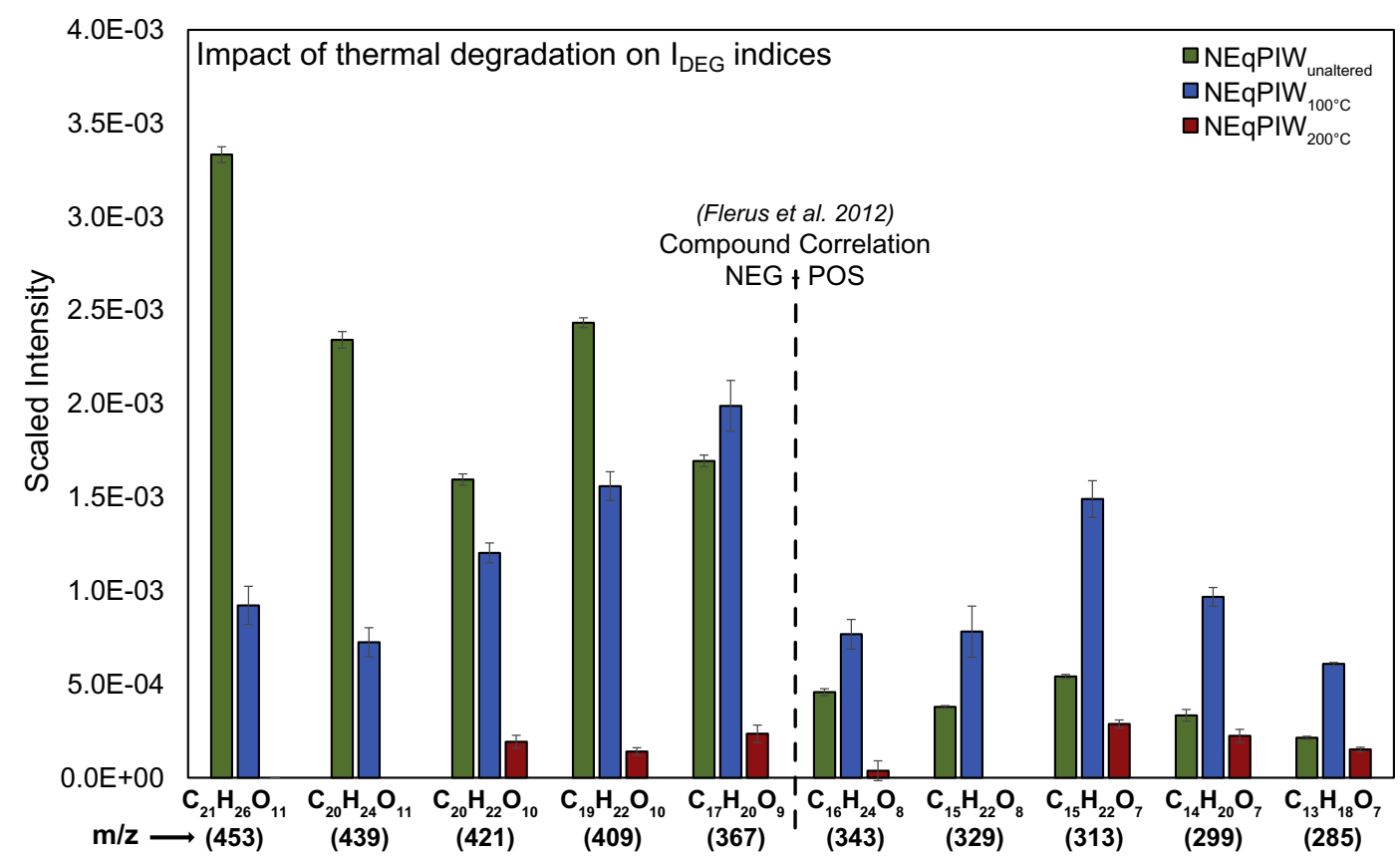

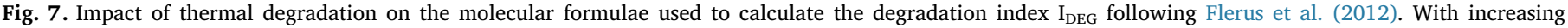

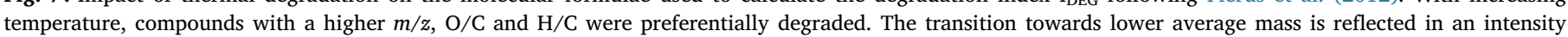

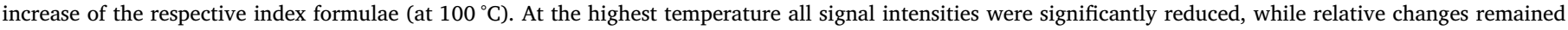
consistent.

which is in line with the observation that the exclusive addition of SPEDOM in the non-heat control C and incubation sets D and E did not stimulate additional prokaryotic growth compared to the unamended control (no addition control). The fact that we still observed growth in the respective incubations can likely be subjected to a bottle effect and incubation conditions not perfectly mimicking the in-situ deep-sea environment (Robinson and Peter, 2007; Sakiyama and Ohwada, 1998). Rossel et al. (2015) also reported virtually unmodified SPE-DOC concentrations from incubations conducted with natural vent fluids and vent endemic microbial communities. A recent experimental study conducted by Arrieta et al. (2015) suggested that a major fraction of SPE-DOM, previously considered intrinsically recalcitrant towards microbial degradation, actually becomes accessible at higher concentration levels. Individual compounds in the highly diverse DOM mixture were presumably too dilute to compensate the metabolic costs associated with their utilization. Accordingly, the addition of SPE-DOM in our experiments should stimulate growth beyond what was observed in the unamended control. But the overall concentration increase introduced in this study was fairly small (well below a 2-fold enrichment), and the concentration-related effect described by Arrieta et al. (2015) only became observable at enrichments significantly exceeding a 2-fold increase in total DOC. Our results thus do not contradict their findings. The respective results hence indicate that the amendment of extractable DOM at this concentration level does not stimulate additional growth regardless of whether its composition was comprehensively changed by a preceding thermal degradation or not.

\subsection{Molecular changes in SPE-DOM induced by hydrothermal treatment}

In addition to the analysis of the bioavailability on a bulk carbon level, hydrothermal and microbial modifications of SPE-DOM were investigated on a molecular level using ultra-high resolution mass spectrometry. The effect of the thermal degradation on SPE-DOM molecular composition was compared with earlier degradation experiments as well as observations made on natural hydrothermal vent samples. The most prominent change was a clear shift towards a lower average molecular mass of the detected formulae decreasing from an $\mathrm{m} / \mathrm{z}$ ratio of $431 \mathrm{Da}$ in the unaltered sample to 355 and $306 \mathrm{Da}$ following thermal degradation at 100 and $200{ }^{\circ} \mathrm{C}$, respectively (Fig. 6). While the detected compounds in all stock solutions continued to follow an intensity distribution along the $\mathrm{m} / \mathrm{z}$ scale in the mass spectra that was bell-shaped, the compositional modification was accompanied by a reduction in average $\mathrm{O} / \mathrm{C}$ ratio $\left(0.43_{\text {unaltered }} \rightarrow 0.36_{100^{\circ} \mathrm{C}} \rightarrow 0.28_{200^{\circ} \mathrm{C}}\right)$, previously interpreted as a successive loss of carboxyl and alcohol groups (Hawkes et al., 2016; McCollom and Seewald, 2003a; Seewald, 2003; Seewald, 2001). Other significant changes (two tailed $t$-test assuming equal variance; $p \leq .01)$ included an increase in overall aromaticity ( $\mathrm{AI}_{\mathrm{mod}}$ : $0.25_{\text {unaltered }} \rightarrow 0.28_{100^{\circ} \mathrm{C}} \rightarrow 0.33_{200^{\circ} \mathrm{C}}$ ) and a decrease in the number of double bonds and rings in a compound (DBE: $8.9_{\text {unaltered }} \rightarrow 7.7_{100^{\circ} \mathrm{C}} \rightarrow$ $7.3_{200^{\circ} \mathrm{C}}$ ) (Table 3). On a compound-group level, polyphenol-like molecules $\left(0.67>\mathrm{AI}_{\text {mod }}>0.5\right)$, highly unsaturated compounds $\left(\mathrm{AI}_{\text {mod }}<0.5\right.$ and $\left.\mathrm{H} / \mathrm{C}<1.5\right)$ and unsaturated aliphatics $(2>\mathrm{H} /$ C $>1.5 ; \mathrm{O} / \mathrm{C}<0.9 ; N=0$ ) made up the major share in all samples, all together they contributed $>85 \%$ to overall intensity. For highly unsaturated molecules, relative abundance of O-rich compounds $(\mathrm{O} /$ $\mathrm{C}>0.5)$ was significantly reduced $\left(20.9 \%_{\text {unaltered }} \rightarrow 6.6 \% 100^{\circ} \mathrm{C} \rightarrow\right.$ $\left.2.0 \%{ }_{200}{ }^{\circ} \mathrm{C}\right)$, while the share of O-poor molecules $(\mathrm{O} / \mathrm{C}<0.5)$ increased at $100{ }^{\circ} \mathrm{C}$ before its share was subsequently reduced at $200^{\circ} \mathrm{C}$ $\left(59.6 \%{ }_{\text {unaltered }} \rightarrow 71.7 \% 100^{\circ} \mathrm{C} \rightarrow 64.1 \%{ }_{200}{ }^{\circ} \mathrm{C}\right)$. Likewise, O-poor polyphenol-like formulae increased in relative abundance only at the highest temperature level $\left(6.6 \%_{\text {unaltered }} \rightarrow 6.2 \%_{100^{\circ} \mathrm{C}} \rightarrow 13.1 \%_{200^{\circ} \mathrm{C}}\right)$. Oxygen-poor unsaturated aliphatics followed a similar pattern as their highly unsaturated counterpart $\left(5.0 \%_{\text {unaltered }} \rightarrow \quad 9.9 \% 100^{\circ} \mathrm{C} \rightarrow\right.$ $9.3 \% 200^{\circ} \mathrm{C}$ ). Changes of formulae that do not fall within one of these groups and that represent the remaining detected compounds were only marginal and are hence not further discussed. In summary, the observations confirm findings of earlier thermal degradation experiments and are in line with carboxyl and hydroxyl groups being apparently randomly and successively split from a wide range of oxygen-rich molecules (Hawkes et al., 2016). Similar changes were reported for a large set of presumably thermally altered samples from different natural hydrothermal vents (Rossel et al., 2017). How does the nature of 


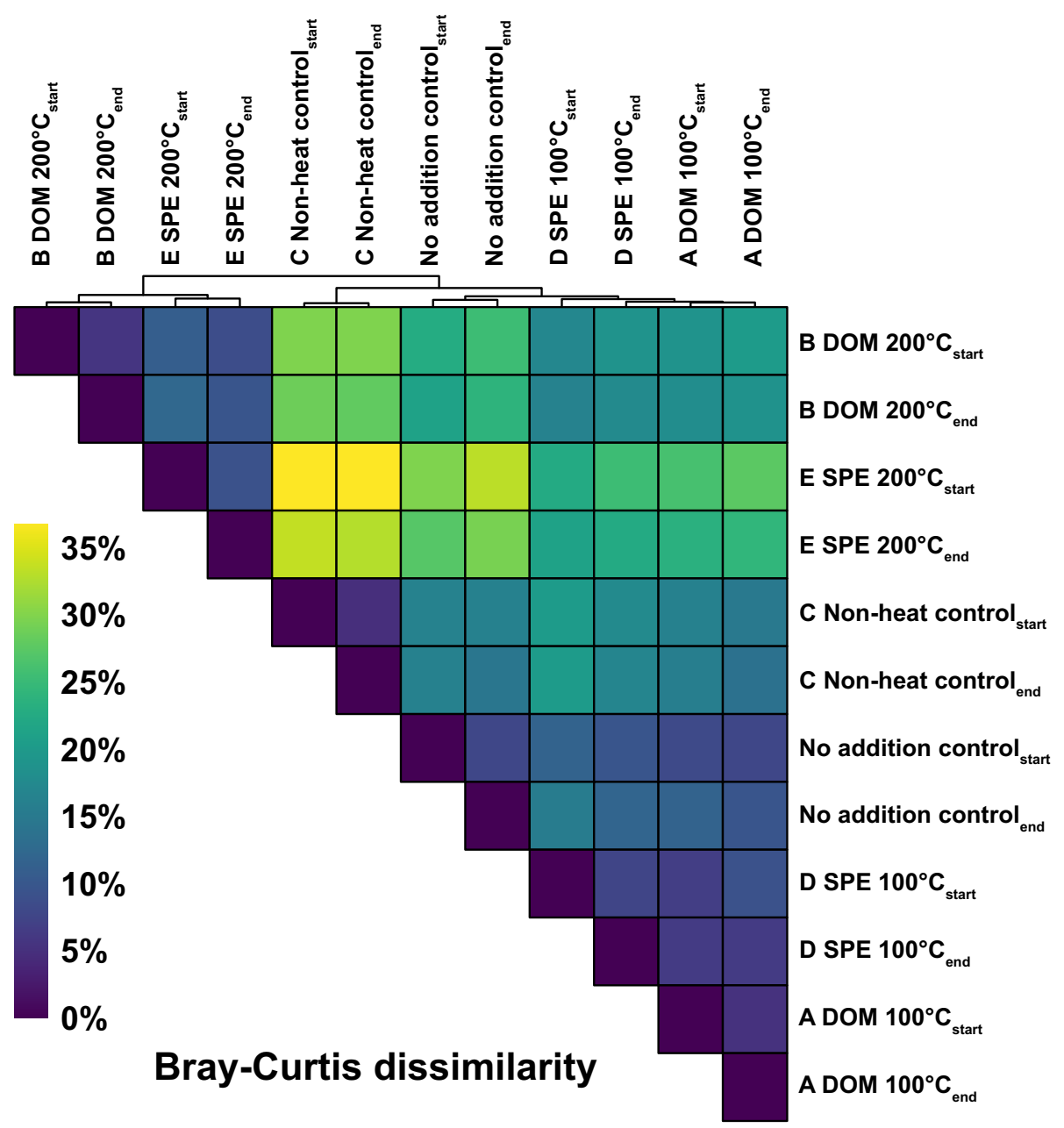

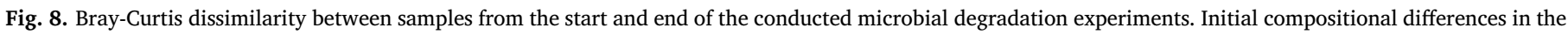

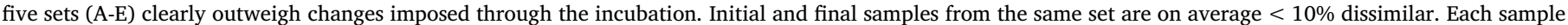
was limited to the 2500 formulae holding the highest peak intensities.

these modifications compare to those occurring during DOM ageing in the water column? Flerus et al. (2012) introduced a degradation index $\mathrm{I}_{\mathrm{DEG}}$ to classify DOM samples with respect to the compositional changes imposed by microbial turnover predominantly in the upper ocean layers. A higher value (on a scale between 0 and 1 ) thereby refers to an older, more degraded state and supposedly a higher fraction of refractory DOM. Thermal degradation had a reverse effect on this indicator, resulting in a significant shift to lower values ( $\mathrm{I}_{\mathrm{DEG}}$ : $0.86_{\text {unaltered }} \rightarrow 0.58_{100^{\circ} \mathrm{C}} \rightarrow 0.45_{200^{\circ} \mathrm{C}}$ ) and an apparently less degraded state, making the respective DOM appear less aged and allegedly increasingly bioavailable in this regard. The modification of $\mathrm{I}_{\mathrm{DEG}}$ through thermal degradation is related to the broad changes in molecular size, aromaticity and oxygen content (Figs. 6 and 7).

\subsection{Molecular changes in SPE-DOM induced by microbial degradation}

The observations that SPE-DOC concentrations did not change during the incubations and that SPE-DOM amendment did not stimulate excess microbial growth suggest that SPE-DOM did not play an important role in the stimulation of microbial growth. Rossel et al. (2015) made a similar observation for diffusive hydrothermal fluids. However, they were able to ultimately identify a certain fraction of SPE-DOM that was subject to compositional changes on a molecular level due to microbial degradation. Consequently, SPE-DOM from the conducted experiments was studied in detail to identify any possible changes induced by microbial activity.
Overall SPE-DOM compositional variability among the samples was evaluated via Principal Coordinate Analysis (PCoA) based on BrayCurtis dissimilarities (Fig. 8). The samples clustered according to the type of DOM added (Fig. 9). Samples with additions of DOM that was altered at $200{ }^{\circ} \mathrm{C}$ and controls were most dissimilar. Within this group, samples with addition of SPE-DOM were more unlike the control than those where bulk DOM was added. This is not surprising because the latter set of samples contained less hydrothermally altered SPE-DOM. Variations along the 1st PCoA axis, accounting for $75 \%$ of SPE-DOM compositional variability, are well explained by temperature differences of the preceding thermal degradation. The 1st PCoA axis correlates significantly with the above discussed thermally-induced changes like average $\mathrm{O} / \mathrm{C}$ ratio, aromaticity $\mathrm{AI}_{\text {mod }}$, $\mathrm{DBE}$ and molecular mass as well as abundance of molecular groups (Fig. 9). Deviations are due to mixing with the pre-existing DOM (Table 3). Compared to the modifications induced by the addition of thermally-altered DOM, microbially-induced changes were very minor. In fact, the Bray-Curtis dissimilarities of the samples taken before and after the incubations (Fig. 8) were in the range of replicate measurements of our in-house NEqPIW reference sample (Table 3). Implications of this observation are discussed further below.

Noticeably, the unamended incubations (no addition control) were less similar to the non-heated control NEqPIW sample than to the samples where thermally-altered DOM $\left(100{ }^{\circ} \mathrm{C}\right)$ was added. This observation suggests that the overall composition of the deep-sea background DOM in the Kermadec Arc is shifted towards a thermally 


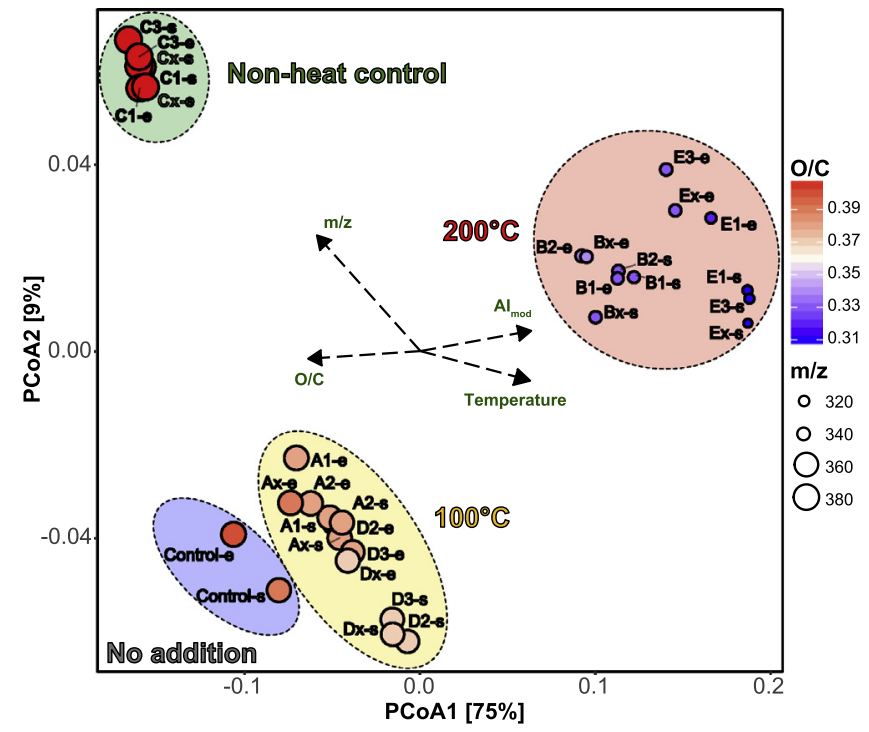

Fig. 9. PCoA depicting SPE-DOM compositional variation for the conducted microbial degradation experiments. Most of the variation is clearly explained by initial differences between the incubation sets with additional unaltered DOM (green) and with DOM previously degraded at $100{ }^{\circ} \mathrm{C}$ (blue) or $200{ }^{\circ} \mathrm{C}$ (red). The PCoA is based on the 2500 most common formulae per sample with respect to intensity. Samples labeled with an ' $x$ ' denote sterile control incubations, whereas suffixes 's' and 'e' refer to the samples taken at the start and upon finalization of the experiment. (For interpretation of the references to colour in this figure legend, the reader is referred to the web version of this article.)

degraded state. Even though the region of the Tonga-Kermadec Arc is known for a large number of submarine volcanoes and associated hydrothermal systems, this observation is remarkable as dilution of the vent fluids is high and it would require an extraordinarily large proportion of water being affected by thermal degradation to cause a detectable hydrothermal signature (De Ronde et al., 2007; Hawkes et al., 2015). Then again, the NEqPIW sample used as a starting material for the autoclavation and the subsequent microbial incubations originates from one of the oldest water masses in the world. Kermadec deep-water DOM might simply be less aged, and, as shown above, thermal alterations result in an apparent reversal of microbial alterations, i.e. thermally altered samples appear less aged than they are (Table 3). The observed similarity of no addition control and hydrothermally modified DOM may be explained by a combination of both effects.

Coming back to the effect of bioincubation on SPE-DOM molecular composition, it is revealing that start and final samples from the same incubations hold almost identical compositions with the lowest intersample dissimilarities (5-10\%) attached when all samples are compared among each other (Figs. 8 and 10). Nevertheless, the PCoA shows a slight but systematic shift along the 2nd axis (accounting for $9 \%$ of total variation). All sterile control samples were also affected by this shift in an indistinguishable manner. Therefore, this minor variation was apparently not related to microbial growth, but possibly due to physicochemical interactions with the incubation bottles or other abiotic storage effects. In addition, the observed comparatively small variation over the course of the incubation (initial versus final sample) regarding average $m / z, \mathrm{O} / \mathrm{C}, \mathrm{AI}_{\text {mod }}$, $\mathrm{DBE}$ and molecular groups is within the analytical variability monitored by repeated measurements of the NEqPIW in-house reference (Table 3). The only possible exception constitutes the incubation with re-extracted hydrothermally $\left(200{ }^{\circ} \mathrm{C}\right)$ altered DOM. Changes over the incubation regarding $\mathrm{m} / \mathrm{z}$, DBE and the peptide-like molecular group slightly exceed the analytical variability at a relatively low significance level (two-sided $t$-test, $p \leq .01$, assuming equal variance; Table 3 ). This particular set initially contained the

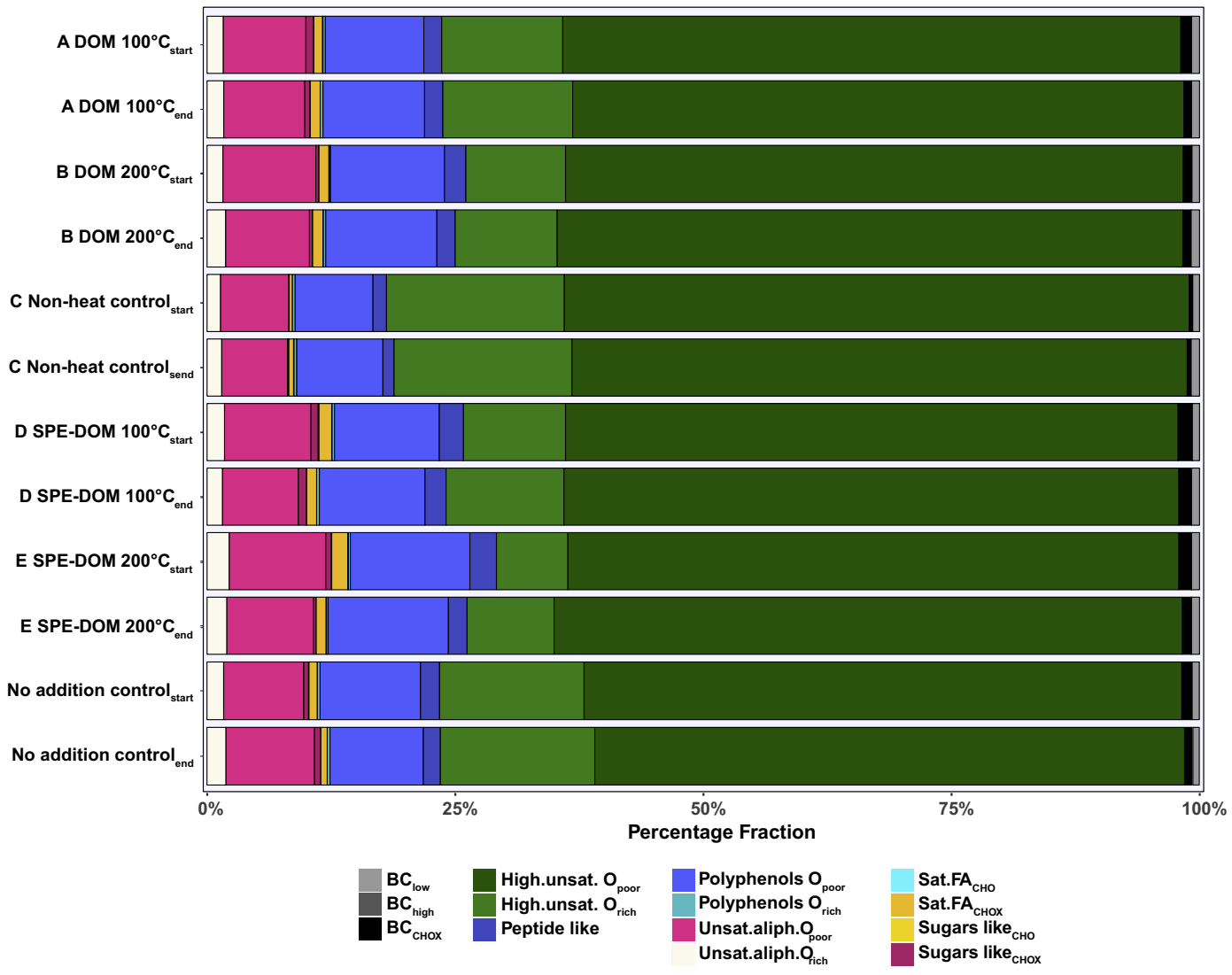

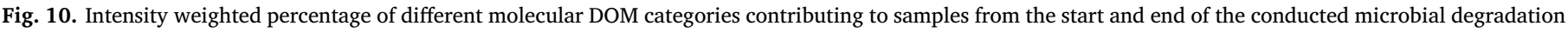
experiments. Each sample was limited to the 2500 formulae holding the highest peak intensities. 
highest amount of the most hydrothermally altered SPE-DOM $\left(200^{\circ} \mathrm{C}\right)$, i.e. DOM which is furthest away from being in equilibrium with the physico-chemical conditions of a deep-sea environment. Thus, it could be speculated if the acquired hydrothermal signature is lost through abiotic, ageing related processes over time (Flerus et al., 2012). But because of the small effect size and the low level of statistical significance we restrain from an in-depth discussion of this observation.

Another noteworthy peculiarity is that calculated values for $I_{D E G}$ seem to imply a particularly high (bio-)lability of re-extracted hydrothermally altered DOM (Table 3 ). Then again, $\mathrm{I}_{\mathrm{DEG}}$ is exclusively defined through some key compounds detectable in SPE-DOM and while the extraction via PPL provides a subset of DOM that is rather representative when it comes to description based on averaged characteristic values like $\mathrm{C} / \mathrm{N}$, the non-extractable fraction can be still fundamentally different especially in terms of bioavailability. The method retains the hydrophobic fraction of DOM which is maximized through protonation in an extraction at low pH (Dittmar et al., 2008; Repeta, 2015). Overall it is more representative for RDOM, the most apolar to highly polar compounds are extracted but not the arguably more bioactive, labile low molecular weight organics (e.g. LMW organic acids, aldehydes and ketones) and colloids. Most identified compounds fall outside the typical $\mathrm{H} / \mathrm{C}-\mathrm{O} / \mathrm{C}$ range, typical for carbohydrates, proteins and lipids and rather hold the characteristics of compounds derived from excessive reworking of these organic compounds (Repeta, 2015). In summary, SPE-DOM represent an arguably biologically rather unreactive DOM fraction that typically co-occurs with a certain bioavailable non-extractable DOM fraction in the marine environment. If this holds true for thermally degraded or reworked DOM, a low $\mathrm{I}_{\mathrm{DEG}}$ could deceptively indicate a highly labile DOM budget when in fact the actually bioactive compounds are mostly missing. This example illustrates the limitations of $\mathrm{I}_{\mathrm{DEG}}$ as a simple measure of lability.

As microbial growth-related changes in SPE-DOM could also be masked by the overwhelming majority of stable compounds, we ultimately performed an additional targeted evaluation. This involved only considering formulae that clearly decreased or increased ( $>25 \%$ variation in normalized intensity) in both replicates, and this change additionally had to be at least $50 \%$ higher than in the corresponding sterile control incubation. The resulting distribution of very few formulae apparently produced or decreased during the incubations followed no systematic pattern. Switching one of the non-sterile replicates with the sterile control incubation in this evaluation procedure produced an indistinguishable pattern, indicating that the small changes in SPE-DOM were not related to microbial activity.

Overall, the comprehensive evaluation of SPE-DOM molecular characteristics is in good agreement with the unchanged SPE-DOC concentrations. It further supports the finding that the extractable DOM fraction of thermally degraded deep-sea organic matter remains inaccessible to microbial degradation despite the broad modification of SPE-DOM molecular characteristics.

\section{Conclusion}

Experiments incubating a deep-sea microbial community from the Kermadec Arc region with a number of unaltered and thermally degraded DOM fractions revealed that strong compositional modifications due to hydrothermal exposure (at 100 and $200{ }^{\circ} \mathrm{C}$ ) result in the formation of bioavailable compounds from previously recalcitrant deepsea DOM. This is the first time experiments could unambiguously confirm that thermal degradation of DOM in the context of seawater cycling through hydrothermal systems is a significant source of labile substrate for deep-sea heterotrophic microorganisms. The magnitude of microbial growth, unchanged SPE-DOC concentrations, as well as the lack of molecular changes in the SPE-DOM fraction during incubations clearly show that the thermogenic, bioavailable compounds exclusively belong to the fraction of DOM that is not extractable by means of solid phase extraction on PPL resins. These non-extractable and labile compounds are likely small ionic compounds, like formate and acetate. Incubations exclusively enriched with extractable SPE-DOM did not show increased prokaryotic growth compared to unenriched controls, independent of whether the DOM was previously thermally degraded or not. This is remarkable, because hydrothermal heating caused comprehensive compositional modification of SPE-DOM. Overall, the results reinforce earlier hypotheses that microbes preferentially utilize small polar compounds produced during thermal degradation of molecularly complex and diverse precursors (Hawkes et al., 2016; McCollom and Seewald, 2003b; Seewald, 2003; Seewald, 2001). Carboxyl and alcohol groups are rather unselectively and successively split from almost the entire range of DOM compounds resulting in reduction of average mass, $\mathrm{O} / \mathrm{C}$ ratio and DBE of the remaining SPE-DOM. Despite these changes, hydrothermally altered DOM did not change in terms of molecular diversity (number and intensity distribution of molecular formulae), which could be the reason for its continuous recalcitrance. Furthermore, the hydrothermally-induced comprehensive molecular modifications of SPE-DOM are largely due to a shift in relative abundance of pre-existing SPE-DOM compounds which continue to be either intrinsically recalcitrant or too diluted to be utilized by microorganisms. There are likely two concomitant reasons for the bioavailability of the hydrothermally produced, non-extractable DOM. Firstly, they must be intrinsically labile. And, secondly, considering the results of experiments conducted by Arrieta et al. (2015), there must be a successive narrowing of diversity and absolutely higher concentrations of the thermogenic compounds eventually pushing them over the concentration threshold at which metabolization becomes feasible.

In our incubations, DOM degraded at the higher temperature stimulated more microbial growth $\left(21 \times\right.$ for $\mathrm{DOM}_{100^{\circ} \mathrm{C}}$ versus $27 \times$ for $\mathrm{DOM}_{200^{\circ} \mathrm{C}}$ ), because the higher temperature resulted in the formation of more non-extractable, labile DOM. Thermal degradation at even higher temperatures results in close to full mineralization and a quantitative removal of DOM (Hawkes et al., 2016; Hawkes et al., 2015). A "hydrothermal sweet spot" seems to exist where a maximum of deep-sea DOM is converted into bio-labile DOM. The exact determination of this temperature in future studies is crucial to quantitatively assess the global role of hydrothermal degradation for the conversion of recalcitrant into labile DOM.

Supplementary data to this article can be found online at https:// doi.org/10.1016/j.marchem.2019.103706.

\section{Acknowledgments}

We are grateful to Captain L. Mallon and his crew of RV Sonne cruise SO253 and Andrea Koschinsky for providing the opportunity to participate and acquire the water samples used in this study. Thanks also go to Corinna Oster for help with the microbial degradation experiments on board and to Janis Thal for providing a map of the sampling area. We further acknowledge help by Ina Ulber with DOC measurements in the lab, by Katrin Klaproth and Helena Osterholz who provided pre-processed FT-ICR-MS data and by Mathias Wolterink for the analysis of prokaryotic abundance by flow cytometry. Finally, we thank Gonzalo Gomez and Patrick Monien for fruitful discussions and comments. This work was funded by the Lower Saxonian Government in Germany within the program Marine Biodiversity Across Scales (MarBAS, VW-Vorab ZN3112) and the Collaborative Research Center Roseobacter (TRR51). We also thank the DFG-funded research center "MARUM - Center for Marine Environmental Sciences" for support.

\section{References}

Arrieta, J.M., Mayol, E., Hansman, R.L., Herndl, G.J., Dittmar, T., Duarte, C.M., 2015. Dilution limits dissolved organic carbon utilization in the deep ocean. Science (80- ). 348, 331-333. https://doi.org/10.1126/science.1258955.

Carlson, C.A., Hansell, D.A., 2015. DOM sources, sinks, reactivity, and budgets. In: Biogeochemistry of Marine Dissolved Organic Matter. Elsevier, pp. 65-126. https:// doi.org/10.1016/B978-0-12-405940-5.00003-0. 
Carlson, C., del Giorgio, P., Herndl, G., 2007. Microbes and the dissipation of energy and respiration: from cells to ecosystems. Oceanography 20, 89-100. https://doi.org/10. 5670/oceanog.2007.52.

De Ronde, C.E.J., Baker, E.T., Massoth, G.J., Lupton, J.E., Wright, I.C., Sparks, R.J., Bannister, S.C., Reyners, M.E., Walker, S.L., Greene, R.R., Ishibashi, J., Faure, K. Resing, J.A., Lebon, G.T., 2007. Submarine hydrothermal activity along the midKermadec arc, New Zealand: large-scale effects on venting. Geochemistry, Geophys. Geosystems 8. https://doi.org/10.1029/2006GC001495.

Dickson, F.W., Blount, C.W., Tunell, G., 1963. Use of hydrothermal solution equipment to determine the solubility of anhydrate in water from $100{ }^{\circ} \mathrm{C}$ to $275{ }^{\circ} \mathrm{C}$ and from 1 bar to 1000 bars pressure. Am. J. Sci. 261, 61-78.

Dittmar, T., Stubbins, A., 2014. Dissolved organic matter in aquatic systems. In: Treatise on Geochemistry. Elsevier, pp. 125-156. https://doi.org/10.1016/B978-0-08095975-7.01010-X.

Dittmar, T., Koch, B., Hertkorn, N., Kattner, G., 2008. A simple and efficient method for the solid-phase extraction of dissolved organic matter (SPE-DOM) from seawater Limnol. Oceanogr. Methods 6, 230-235. https://doi.org/10.4319/lom.2008.6.230.

Druffel, E.R.M., Williams, P.M., 1990. Identification of a deep marine source of particulate organic carbon using bomb 14C. Nature 347, 172-174. https://doi.org/10.1038/ $347172 \mathrm{a} 0$.

Druffel, E.R., Griffin, S., Bauer, J., Wolgast, D., Wang, X.-C., 1998. Distribution of particulate organic carbon and radiocarbon in the water column from the upper slope to the abyssal NE Pacific Ocean. Deep Sea Res. Part II Top. Stud. Oceanogr. 45, 667-687. https://doi.org/10.1016/S0967-0645(98)00002-2.

Ducklow, H.W., Steinberg, D.K., Buesseler, K.O., 2001. Upper ocean carbon export and the biological pump. Oceanogr. Dc-Oceanography Soc. 14, 50-58.

Eiler, A., Langenheder, S., Bertisson, S., Tranvik, L.J., 2003. Heterotrophic bacterial growth efficiency and community structure at different natural organic carbon concentrations. Appl. Environ. Microbiol. 69, 3701-3709. https://doi.org/10.1128/ AEM.69.7.3701.

Flerus, R., Lechtenfeld, O.J., Koch, B.P., McCallister, S.L., Schmitt-Kopplin, P., Benner, R., Kaiser, K., Kattner, G., 2012. A molecular perspective on the ageing of marine dissolved organic matter. Biogeosciences 9, 1935-1955. https://doi.org/10.5194/bg-91935-2012.

Giebel, H.-A., Wolterink, M., Brinkhoff, T., Simon, M., 2019. Complementary energy acquisition via aerobic anoxygenic photosynthesis and carbon monoxide oxidation by Planktomarina temperata of the Roseobacter group. FEMS Microbiol. Ecol. 95, fiz050. https://doi.org/10.1093/femsec/fiz050.

del Giorgio, P., Cole, J.J., Cimbleris, A., 1997. Respiration rates in bacteria exceed phytoplankton production in unproductive aquatic systems. Nature. https://doi.org/10. 1038/385148a0.

Gonsior, M., Hertkorn, N., Hinman, N., Dvorski, S.E.M., Harir, M., Cooper, W.J., SchmittKopplin, P., 2018. Yellowstone Hot Springs are organic chemodiversity hot spots. Sci. Rep. 8, 1-13. https://doi.org/10.1038/s41598-018-32593-x.

Green, N.W., Perdue, E.M., Aiken, G.R., Butler, K.D., Chen, H., Dittmar, T., Niggemann, J., Stubbins, A., 2014. An intercomparison of three methods for the large-scale isolation of oceanic dissolved organic matter. Mar. Chem. 161, 14-19. https://doi.org/10. 1016/j.marchem.2014.01.012.

Hansell, D., 2013. Recalcitrant dissolved organic carbon fractions. Annu. Rev. Mar. Sci. 5https://doi.org/10.1146/annurev-marine-120710-100757. 120717164858000.

Hansell, D.A., Carlson, C.A., Repeta, D.J., Schlitzer, R., 2009. Dissolved organic matter in the ocean a controversy stimulates new insights. Oceanography 22, 202-211. https:// doi.org/10.5670/oceanog.2009.109.

Hansell, D.A., Carlson, C.A., Schlitzer, R., 2012. Net removal of major marine dissolved organic carbon fractions in the subsurface ocean. Glob. Biogeochem. Cycles 26, 1-9. https://doi.org/10.1029/2011GB004069.

Hansman, R.L., Dittmar, T., Herndl, G.J., 2015. Conservation of dissolved organic matter molecular composition during mixing of the deep water masses of the northeas Atlantic Ocean. Mar. Chem. 177, 288-297. https://doi.org/10.1016/j.marchem. 2015.06.001.

Hawkes, J.A., Rossel, P.E., Stubbins, A., Butterfield, D., Connelly, D.P., Achterberg, E.P., Koschinsky, A., Chavagnac, V., Hansen, C.T., Bach, W., Dittmar, T., 2015. Efficient removal of recalcitrant deep-ocean dissolved organic matter during hydrothermal circulation. Nat. Geosci. 8, 856-860. https://doi.org/10.1038/ngeo2543.

Hawkes, J.A., Hansen, C.T., Goldhammer, T., Bach, W., Dittmar, T., 2016. Molecular alteration of marine dissolved organic matter under experimental hydrothermal conditions. Geochim. Cosmochim. Acta 175, 68-85. https://doi.org/10.1016/j.gca. 2015.11.025.

Hertkorn, N., Harir, M., Koch, B.P., Michalke, B., Schmitt-Kopplin, P., 2013. High-field NMR spectroscopy and FTICR mass spectrometry: powerful discovery tools for the molecular level characterization of marine dissolved organic matter. Biogeosciences 10, 1583-1624. https://doi.org/10.5194/bg-10-1583-2013.

Heuer, V., Elvert, M., Tille, S., Krummen, M., Mollar, X.P., Hmelo, L.R., 2006. Online $\delta 13$ $\mathrm{C}$ analysis of volatile fatty acids in sediment / porewater systems by liquid chromatography - isotope ratio mass spectrometry. Limnol. Oceanogr. Methods 4 , 346-357. https://doi.org/10.4319/lom.2006.4.346.

Heuer, V.B., Pohlman, J.W., Torres, M.E., Elvert, M., Hinrichs, K.-U., 2009. The stable carbon isotope biogeochemistry of acetate and other dissolved carbon species in deep subseafloor sediments at the northern Cascadia margin. Geochim. Cosmochim. Acta 73, 3323-3336. https://doi.org/10.1016/j.gca.2009.03.001.

Jiao, N., Herndl, G.J., Hansell, D.A., Benner, R., Kattner, G., Wilhelm, S.W., Kirchman, D.L., Weinbauer, M.G., Luo, T., Chen, F., Azam, F., 2010. Microbial production of recalcitrant dissolved organic matter: long-term carbon storage in the global ocean. Nat. Rev. Microbiol. 8, 593-599. https://doi.org/10.1038/nrmicro2386.

Kaiser, K., Benner, R., 2012. Organic matter transformations in the upper mesopelagic zone of the North Pacific: chemical composition and linkages to microbial community structure. J. Geophys. Res. Ocean. 117, 1-12. https://doi.org/10.1029/ 2011JC007141.

Kester, D.R., Duedall, I.W., Connors, D.N., Pytkowicz, R.M., 1967. Preparation of artificial seawater. Limnol. Oceanogr. 12, 176-179. https://doi.org/10.4319/lo.1967.12.1. 0176 .

Koch, B.P., Dittmar, T., 2006. From mass to structure: an aromaticity index for highresolution mass data of natural organic matter. Rapid Commun. Mass Spectrom. 20, 926-932. https://doi.org/10.1002/rcm.2386.

Koch, B.P., Dittmar, T., 2016. Erratum: from mass to structure: an aromaticity index for high-resolution mass data of natural organic matter (Rapid Communications in Mass Spectrometry (2006) 20 (926-932) DOI: https://doi.org/10.1002/rcm.2386). Rapid Commun. (Mass Spectrom. 30, 250. doi:10.1002/rcm.7433)

Koch, B.P., Witt, M., Engbrodt, R., Dittmar, T., Kattner, G., 2005. Molecular formulae of marine and terrigenous dissolved organic matter detected by electrospray ionization Fourier transform ion cyclotron resonance mass spectrometry. Geochim. Cosmochim. Acta 69, 3299-3308. https://doi.org/10.1016/j.gca.2005.02.027.

Konn, C., Charlou, J.L., Donval, J.P., Holm, N.G., Dehairs, F., Bouillon, S., 2009. Hydrocarbons and oxidized organic compounds in hydrothermal fluids from rainbow and lost City ultramafic-hosted vents. Chem. Geol. 258, 299-314. https://doi.org/10. 1016/j.chemgeo.2008.10.034.

Koschinsky, A., 2017. RV Sonne 253 Cruise Report. Bremen. https://doi.org/10.2312/cr so253.

Kragh, T., Søndergaard, M., 2009. Production and decomposition of new DOC by marine plankton communities: carbohydrates, refractory components and nutrient limitation. Biogeochemistry 96, 177-187. https://doi.org/10.1007/s10533-009-9357-1.

Lang, S.Q., Butterfield, D.A., Schulte, M., Kelley, D.S., Lilley, M.D., 2010. Elevated concentrations of formate, acetate and dissolved organic carbon found at the lost City hydrothermal field. Geochim. Cosmochim. Acta 74, 941-952. https://doi.org/10. 1016/j.gca.2009.10.045.

Loh, A.N., Bauer, J.E., Druffel, E.R.M., 2004. Variable ageing and storage of dissolved organic components in the open ocean. Nature 430, 877-881. https://doi.org/10. 1038/nature02780

McCarthy, M.D., Beaupré, S.R., Walker, B.D., Voparil, I., Guilderson, T.P., Druffel, E.R.M., 2011. Chemosynthetic origin of 14C-depleted dissolved organic matter in a ridgeflank hydrothermal system. Nat. Geosci. 4, 32-36. https://doi.org/10.1038/ ngeo1015.

McCollom, T.M., Seewald, J.S., 2003a. Experimental constraints on the hydrothermal reactivity of organic acids and acid anions: I. formic acid and formate. Geochim. Cosmochim. Acta 67, 3625-3644. https://doi.org/10.1016/S0016-7037(03) 00136-4.

McCollom, T.M., Seewald, J.S., 2003b. Experimental study of the hydrothermal reactivity of organic acids and acid anions: II. Acetic acid, acetate, and valeric acid. Geochim. Cosmochim. Acta 67, 3645-3664. https://doi.org/10.1016/S0016-7037(03) 00135-2.

McCollom, T.M., Seewald, J.S., 2007. Abiotic synthesis of organic compounds in deep-sea hydrothermal environments. Chem. Rev. 107, 382-401. https://doi.org/10.1021/ cr0503660.

Oksanen, J., Blanchet, F.G., Friendly, M., Kindt, R., Legendre, P., McGlinn, D., Minchin, P.R., O'Hara, R.B., Simpson, G.L., Solymos, P., Henry, M., Stevens, H., Szoecs, E., Wagner, H., 2017. Vegan: community ecology package. R package version 2 4-3. https://CRAN.R-project.org/package = vegan.

Repeta, D.J., 2015. Chemical characterization and cycling of dissolved organic matter. In: Biogeochemistry of Dissolved Organic Matter, pp. 21-64.

Riedel, T., Dittmar, T., 2014. A method detection limit for the analysis of natural organic matter via Fourier transform ion cyclotron resonance mass spectrometry. Anal. Chem. 86, 8376-8382. https://doi.org/10.1021/ac501946m.

Robinson, C., Peter, P.J., 2007. Respiration and its measurement in surface marine waters. Respir. Aquat. Ecosyst. https://doi.org/10.1093/acprof:oso/9780198527084. 003.0009.

de Ronde, C.E.J., Stucker, V.K., 2015. Seafloor hydrothermal venting at volcanic arcs and Backarcs. In: The Encyclopedia of Volcanoes. Elsevier, pp. 823-849. https://doi.org/ 10.1016/B978-0-12-385938-9.00047-X.

Rossel, P.E., Stubbins, A., Hach, P.F., Dittmar, T., 2015. Bioavailability and molecular composition of dissolved organic matter from a diffuse hydrothermal system. Mar Chem. 177, 257-266. https://doi.org/10.1016/j.marchem.2015.07.002.

Rossel, P.E., Stubbins, A., Rebling, T., Koschinsky, A., Hawkes, J.A., Dittmar, T., 2017. Thermally altered marine dissolved organic matter in hydrothermal fluids. Org. Geochem. 110, 73-86. https://doi.org/10.1016/j.orggeochem.2017.05.003.

Sakiyama, T., Ohwada, K., 1998. Effect of hydrostatic pressure on the growth of deep-sea bacterial communities. Proc. NIPR Symp. Polar Biol. 11, 1-7.

Seewald, J.S., 2001. Aqueous geochemistry of low molecular weight hydrocarbons at elevated temperatures and pressures: constraints from mineral buffered laboratory experiments. Geochim. Cosmochim. Acta 65, 1641-1664. https://doi.org/10.1016/ S0016-7037(01)00544-0.

Seewald, J.S., 2003. Organic-inorganic interactions in petroleum-producing sedimentary basins. Nature 426, 327-333. https://doi.org/10.1038/nature02132.

Seyfried, W.E., Janecky, D.R., Berndt, M.E., 1987. Rocking autoclaves for hydrothermal experiments. II. The flexible reaction-cell system. In: Hydrothermal Experimental Techniques. Wiley-Interscience Publications, pp. 216-239.

Simon, M., Azam, F., 1989. Protein content and protein synthesis rates of planktonic marine bacteria. Mar. Ecol. Prog. Ser. 51, 201-213. https://doi.org/10.3354/ meps051201.

Stubbins, A., Niggemann, J., Dittmar, T., 2012. Photo-lability of deep ocean dissolved black carbon. Biogeosciences 9, 1661-1670. https://doi.org/10.5194/bg-9-1661 2012.

Wienhausen, G., Noriega-Ortega, B.E., Niggemann, J., Dittmar, T., Simon, M., 2017. The 
exometabolome of two model strains of the Roseobacter group: a marketplace of microbial metabolites. Front. Microbiol. 8, 1-15. https://doi.org/10.3389/fmicb. 2017.01985.

Williams, P.M., Druffel, E.R.M., 1987. Radiocarbon in dissolved organic matter in the central North Pacific Ocean. Nature 330, 246-248. https://doi.org/10.1038/ $330246 \mathrm{a} 0$.

Windman, T., Zolotova, N., Schwandner, F., Shock, E.L., 2007. Formate as an energy source for microbial metabolism in chemosynthetic zones of hydrothermal ecosystems. Astrobiology 7, 873-890. https://doi.org/10.1089/ast.2007.0127.
Winkel, M., Pjevac, P., Kleiner, M., Littmann, S., Meyerdierks, A., Amann, R., Mußmann, M., 2014. Identification and activity of acetate-assimilating bacteria in diffuse fluids venting from two deep-sea hydrothermal systems. FEMS Microbiol. Ecol. 90,

731-746. https://doi.org/10.1111/1574-6941.12429.

Zark, M., Christoffers, J., Dittmar, T., 2017. Molecular properties of deep-sea dissolved organic matter are predictable by the central limit theorem: evidence from tandem FT-ICR-MS. Mar. Chem. 191, 9-15. https://doi.org/10.1016/j.marchem.2017.02. 005 